\title{
Observed and Projected Impacts of Climate Change on Marine Fisheries, Aquaculture, Coastal Tourism, and Human Health: An Update
}

\author{
Lauren V. Weatherdon ${ }^{1,2 *}$, Alexandre K. Magnan ${ }^{3}$, Alex D. Rogers ${ }^{4}$, U. Rashid Sumaila ${ }^{5}$ \\ and William W. L. Cheung ${ }^{1,6}$ \\ ${ }^{1}$ Changing Ocean Research Unit, Global Fisheries Cluster, Institute for the Oceans and Fisheries, The University of British \\ Columbia, Vancouver, BC, Canada, ${ }^{2}$ UNEP World Conservation Monitoring Centre, Cambridge, UK, ${ }^{3}$ Institute for \\ Sustainable Development and International Relations, Paris, France, ${ }^{4}$ Department of Zoology, University of Oxford, Oxford, \\ UK, ${ }^{5}$ Fisheries Economics Research Unit, Global Fisheries Cluster, Institute for the Oceans and Fisheries, The University of \\ British Columbia, Vancouver, BC, Canada, ${ }^{6}$ Nippon Foundation - University of British Columbia Nereus Program, Institute for \\ the Oceans and Fisheries, The University of British Columbia, Vancouver, BC, Canada
}

\section{OPEN ACCESS}

Edited by:

Elvira S. Poloczanska,

Commonwealth Scientific and Industrial Research Organisation,

Australia

Reviewed by:

Athanassios C. Tsikliras, Aristotle University of Thessaloniki,

Greece

Mark R. Payne

Technical University of Denmark,

Denmark

*Correspondence:

Lauren V. Weatherdon

lauren.weatherdon@unep-wcmc.org

Specialty section:

This article was submitted to Global Change and the Future Ocean,

a section of the journal

Frontiers in Marine Science

Received: 30 November 2015 Accepted: 29 March 2016 Published: 19 April 2016

Citation:

Weatherdon LV, Magnan AK

Rogers $A D$, Sumaila UR and Cheung WWL (2016) Observed and Projected Impacts of Climate Change on Marine Fisheries, Aquaculture, Coastal Tourism, and Human Health: An Update. Front. Mar. Sci. 3:48. doi: 10.3389/fmars.2016.00048
The Intergovernmental Panel on Climate Change (IPCC) Fifth Assessment Report (AR5) states that climate change and ocean acidification are altering the oceans at a rate that is unprecedented compared with the recent past, leading to multifaceted impacts on marine ecosystems, associated goods and services, and human societies. AR5 underlined key uncertainties that remain regarding how synergistic changes in the ocean are likely to affect human systems, and how humans are likely to respond to these events. As climate change research has accelerated rapidly following AR5, an updated synthesis of available knowledge is necessary to identify emerging evidence, and to thereby better inform policy discussions. This paper reviews the literature to capture corroborating, conflicting, and novel findings published following the cut-off date for contribution to AR5. Specifically, we highlight key scientific developments on the impacts of climate-induced changes in the ocean on key socioeconomic sectors, including fisheries, aquaculture, and tourism. New evidence continues to support a climate-induced redistribution of benefits and losses at multiple scales and across coastal and marine socio-ecological systems, partly resulting from species and ecosystem range shifts and changes in primary productivity. New efforts have been made to characterize and value ecosystem services in the context of climate change, with specific relevance to ecosystem-based adaptation. Recent studies have also explored synergistic interactions between climatic drivers, and have found strong variability between impacts on species at different life stages. Although climate change may improve conditions for some types of freshwater aquaculture, potentially providing alternative opportunities to adapt to impacts on wild capture fisheries, ocean acidification poses a risk to shellfish fisheries and aquaculture. The risk of increased prevalence of disease under warmer temperatures is uncertain, and may detrimentally affect human health. Climate change may also induce changes in tourism flows, leading to substantial geospatial shifts in economic costs and benefits associated with tourism revenue and coastal infrastructure protection and repairs. While promising, ecosystem-based coastal adaptation approaches are still emerging, and 
require an improved understanding of key ecosystem services, and values for coastal communities in order to assess risk, aid coastal development planning, and build decision support systems.

Keywords: climate change impacts, fisheries, aquaculture, coastal tourism, human health, food security, ecosystem-based adaptation, ocean impacts

\section{INTRODUCTION}

The Intergovernmental Panel on Climate Change (IPCC) Fifth Assessment Report (AR5) states that climate change and ocean acidification are altering the global ocean at a rate that is unprecedented compared with the recent past, leading to multifaceted impacts on marine and coastal ecosystems, associated goods and services, and human societies (Church et al., 2013; Pörtner H. O. et al., 2014; Howes et al., 2015). Specifically, Working Group II (WGII) of the IPCC synthesized research regarding the observed and projected impacts of climate change on human and ecological systems. AR5 represents the first IPCC report to allocate two separate chapters to the ocean within WGII, thereby demonstrating the important contributions of the marine environment to discussions regarding climate change impacts and adaptation options.

As research regarding climate change, ocean acidification, and the ocean has accelerated rapidly, it is important to update the synthesis of available knowledge on these topics regularly to inform policy discussions. As a result of the need to ensure timely publication and peer review, the IPCC could only consider literature that had been published prior to August 2013 and now more than 2 years since WGII's deadline for inclusion of published literature have passed. Research findings published within this subsequent period may strengthen or alter the assessments and conclusions drawn in AR5.

To summarize progress toward addressing the uncertainties identified in AR5, this paper highlights key developments with respect to scientific understanding of the impacts of climate-induced changes in marine and coastal environments on socioeconomic sectors and human health, with a brief discussion on recent research regarding adaptation strategies that build from the AR5. Specifically, this review focuses on topics related to fisheries, aquaculture, and coastal tourism, as well as human health and food security, with the aim to capture corroborating, conflicting, and novel findings from literature published after the literature "cut-off date" of the IPCC report. To achieve this, the authors identified key findings from WGII of the IPCC's AR5 on $\mathrm{CO}_{2}$-related impacts on living marine resources of importance to key marine and coastal sectors. Then, we undertook a systematic review of literature on these topics. Finally, we concluded by identifying areas of agreement and points of departure from the IPCC's AR5.

\section{KEY FINDINGS IN IPCC AR5}

Key findings from AR5 focused primarily on the ecological implications of climate change (Pörtner H. O. et al., 2014; Howes et al., 2015). In particular, global redistribution of marine species was highlighted, with observations and projections supporting further poleward range shifts under increased ocean temperatures (Poloczanska et al., 2014; Pörtner H. O. et al., 2014). Community size structures were projected to decrease under climate change, with reductions in maximum body sizes expected to occur in response to increased temperatures and reduced oxygen supply (Cheung et al., 2013b). Studies have indicated that impacts of acidification are likely to be both positive and negative, with severe impacts on calcifying organisms such as reefbuilding corals and bivalves, but with potential benefits for some vegetative habitats, such as seagrasses (Gattuso et al., 2014a). Net primary productivity (NPP) was projected to decrease moderately in the open ocean by 2100 under both low- and highemission scenarios, comprising a mean increase in NPP at high latitudes and a decrease in the tropics (Boyd et al., 2014).

AR5 also highlighted socioeconomic impacts of climate change on coastal communities. Projections indicated that species' poleward range shifts would likely negatively impact tropical and subtropical communities that depend on these species for food and economic security (Pörtner H. O. et al., 2014). Adaptation options included maintaining important ecosystems, ensuring occupational flexibility, and developing early warning systems for extreme events (Portner J. R. et al., 2014). Other coastal impacts discussed included the prominent threat of sea level rise (SLR), the vulnerability of low-lying coastal areas, islands, and polar regions (Larsen et al., 2014; Nurse et al., 2014) and, to a lesser extent, impacts on coastal tourism through poleward redistribution of tourism flows associated with increased temperatures, loss of beaches through coastal erosion and SLR, and a reduction in water supplies (Wong et al., 2014). At the time, global estimates of observed or projected economic costs associated with ocean acidification were limited (Gattuso et al., 2014a), while evidence of impacts on human health focused primarily on increased frequency of disease transmission and range expansion, deaths associated with storm surges and flooding, increased prevalence of harmful algal blooms (HABs), and reduced food and water security (Nurse et al., 2014; Pörtner H. O. et al., 2014; Wong et al., 2014). The report called for additional research exploring climate-related impacts on other coastal sectors, such as tourism (Wong et al., 2014) and aquaculture (Portner J. R. et al., 2014).

AR5 underlined key uncertainties regarding how synergistic climate-induced changes in ecological systems are likely to affect human systems (Larsen et al., 2014; Pörtner H. O. et al., 2014), and how humans are likely to respond to climatedriven events (Portner J. R. et al., 2014). For instance, the capacity for different taxa to track or acclimate to (i.e., alter functional or morphological traits in response to) changes in climate and multiple stressors remained uncertain, with few studies addressing adaptation to multiple stressors over longer time series (Poloczanska et al., 2014; Pörtner 
H. O. et al., 2014). Limited evidence existed regarding the directionality and magnitude of changes in NPP across different regions and ecosystems (Boyd et al., 2014) and, while acknowledged as a critical process influencing ecosystem productivity, the likelihood of climate-induced changes to major upwelling systems through increased or decreased upwelling remained uncertain (Lluch-Cota et al., 2014). Similarly, while the processes behind ocean acidification were well-understood, few comprehensive studies of biological, ecological, and biogeochemical impacts were available (Gattuso et al., 2014a). While climate change was projected to alter the yield, distribution, quality, and composition of fisheries' landings globally, details regarding these projected changes, such as quantification of risk and uncertainties, were still limited (Cheung et al., 2013c). Although socioeconomic vulnerability was projected to be highest in tropical countries (Pörtner H. O. et al., 2014), examples of successful adaptation for small island nations-beyond relocation-were limited and assessments of the social and economic costs of adaptation options were seldom available (Nurse et al., 2014), with relative costs of adaptation varying strongly between and within regions (Wong et al., 2014). Ecosystem-based adaptation also featured strongly in the report as a potential option for responding to climate change, yet examples were too few and too recent to facilitate a comprehensive assessment of benefits and risks (Shaw et al., 2014). Critically, authors of AR5 noted that the practice of adaptation often exceeds the rate at which peer-reviewed research describing and examining these practices can be produced and disseminated (Noble et al., 2014). Thus our knowledge of the effectiveness of these adaptation practices often lags behind their implementation.

\section{SYSTEMATIC REVIEW OF LITERATURE}

A search of the peer-reviewed literature was conducted to identify recent scientific developments globally with respect to our understanding of the impacts of greenhouse gas emissions on marine and coastal ecosystems and the sectors and communities that depend on them. Relevant studies, including regional examples where available, were obtained by browsing issues published in peer-reviewed journals between 1 January, 2013 and 31 October, 2014. The literature review was guided by the questions outlined in Table 1.

While the study does not intend to provide a comprehensive overview of climate-induced impacts on marine systems (see Howes et al., 2015), an understanding of the effects of ocean warming and acidification on living marine resources was required to examine corresponding impacts on coastal sectors and communities. Thus, the study examines relationships between ecological and socioeconomic impacts arising from climate change, focusing on impacts likely to occur within the twenty-first century.

\section{Fisheries and Auxiliary Sectors}

Healthy marine systems play a critical role in supporting fisheries, which contribute significantly to jobs, food security, and the wealth of nations. Recent studies have sought to characterize how climate-related drivers alter species' distributions and community size structures, with increased attention allocated toward synergistic effects (Hollowed et al., 2013; Brown and Thatje, 2014), early developmental stages and community size structures (Suikkanen et al., 2013; Woodworth-Jefcoats et al., 2013; Baudron et al., 2014; Calbet et al., 2014; Lefort et al., 2014), and genetic and phenotypic adaptation (Munday et al., 2013; Merilä and Hendry, 2014; Sunday et al., 2014). Each of these aspects is likely to affect the availability and abundance of fish stocks globally (Sumaila et al., 2011), with regional variation accompanying climatic trends. From an operational perspective, studies have also noted that changes in the frequency of extreme weather events may cause disruptions to fishing activities and land-based fisheries-related infrastructure (Noone et al., 2013).

TABLE 1 | Questions used to guide the literature review.

\section{Topic}

Fisheries

Coastal tourism

Human health

Coastal adaptation

\section{Question}

How are climate change drivers expected to impact fish stocks (distribution, composition, quantity of individuals, etc.) that are currently exploited?

How are these changes expected to vary by ecosystem and geographical region?

How are these impacts expected to affect fisheries' catch potential?

What economic impacts are expected for fishing and auxiliary industries?

How are these impacts expected to alter food security?

What ramifications may arise with respect to multilateral business agreements and international agreements? What geopolitical impacts are likely to occur?

What new evidence supports the theory of an emerging "winners and losers" gap?

How is climate change expected to impact future shellfish and fish aquaculture?

What are the projected consequences of changes in aquaculture production on global food and economic security?

What are the consequences of ocean warming and acidification impacts on tourism flows?

What are the consequences of ocean warming and acidification impacts on tourism operators' strategies?

What are the economic consequences to be expected from ocean warming and acidification?

What are the possible impacts of climate-related drivers (e.g., diminished food and water security; extreme weather events; increased prevalence and transmission of disease) on human health?

What evidence exists of the capacity for coastal communities and sectors to mitigate and adapt to climate change? 


\section{Projected Impacts on the Distribution of Fisheries Stocks}

Empirical and theoretical evidence of range shifts in response to temperature gradients has continued to emerge for various taxa across many geographical locations (Poloczanska et al., 2013; Bates et al., 2014), with observations supporting the hypothesis that range shifts correspond with the rate and directionality of climate shifts_or "climate velocity" - across landscapes (Pinsky et al., 2013). In fact, variation in climate velocity was discovered to be a stronger predictor of the directionality and magnitude of taxon shifts than variations in life histories (Pinsky et al., 2013).

Studies have increasingly evaluated the degree to which taxa can track these climate velocities, with an aim to understand the factors that constrain range extension or contraction processes (Burrows et al., 2014). Supporting previous findings, Arctic and tropical fishes have been found occupying new habitats as temperatures change, further demonstrating the likelihood of continued poleward range shifts under ocean warming (Wenger et al., 2013). For instance, tropical fish species with larger body sizes, greater swimming capacities, larger sizes at settlement, and pelagic spawning behavior have exhibited greater success when colonizing temperate habitats, while habitat and food limitation during juvenile stages were likely to constrain movement (Feary et al., 2013). Latitudinal trends also suggest that fisheries stock sizes can increase polewards through higher growth rates accompanying increased temperatures, with a corresponding redistribution of fishing effort polewards (Hamon et al., 2013). However, recruitment is expected to exhibit an eventual decline under climate change, and thereby partially or fully counteract projected benefits (Hamon et al., 2013). Observed range shifts associated with ocean warming may also result in hybridization between native and invasive species through overlapping ranges, leading to reduced fitness and thus potentially increasing the risks of genetic extinction and reducing adaptability to environmental changes (Muhlfeld et al., 2014).

New examples have emerged regarding barriers to migration, with studies demonstrating that some taxa may be incapable of keeping pace with climate velocities, as observed with benthic invertebrates in the North Sea (Hiddink et al., 2014), and that there may be geographical barriers to migration associated with "climate sinks," where local climatic conditions differ from the temperature gradients tracked by migrating species (Burrows et al., 2014). Moreover, genetic bottlenecks can emerge where species exhibit limited dispersal capacity because of a lack of suitable habitat, thereby preventing population connectivity (e.g., lack of gene flow between populations of corkwing wrasse, Symphodus melops, in the North Sea and Portugal) (Knutsen et al., 2013). Significant correlation has been found between hypoxia thresholds and hyperbaric thresholds of taxonomic groups, suggesting that the synergistic effects of temperature, pressure, and oxygen concentration may constrain the capacity of marine invertebrates and fishes to respond to changes in environmental conditions through range shifts (Brown and Thatje, 2014). These results corroborate previous projections that polar species-and thus the fisheries that target them-are likely to be more vulnerable to climate change due to constrained ecological niches (e.g., Cheung et al., 2009), and further suggest that tropical and temperate fauna may experience substantial range expansion under the combined influence of ocean warming and deoxygenation (Brown and Thatje, 2014). Indeed, in some locations, it is thought that hypoxia may function as a greater driver of poleward shifts than warming (e.g., poleward shifts of southern groundfish communities in the Pacific Northwest basin Okey et al., 2014).

Climate-induced local (i.e., landward) and global (i.e., poleward) range shifts are also likely to occur for shallow tropical water systems and coastal mangroves, which support fisheries by providing nursery grounds and sheltered habitats that are critical for many species. Mangrove habitats are expected to respond to higher temperatures and $\mathrm{CO}_{2}$ concentrations through poleward range shifts and faster growth rates, with species richness increasing at higher latitudes (Ross and Adam, 2013). Southern and eastern range expansions have already been reported in Australia (Ross and Adam, 2013). While research suggests that mangroves may be able to migrate landwards in response to low scenarios of SLR (e.g., Gazi Bay in Mombasa, Africa), adaptation probabilities have been shown to decrease under higher rates of SLR due to saline intrusion (Di Nitto et al., 2014), accompanied by decreased growth rates (Mitra, 2013). Species-specific adaptation is also influenced by interspecific competition and recruitment strength, which may alter community composition within mangrove forests (Di Nitto et al., 2014). Thus, evidence of the capacity of coastal habitats such as saltmarshes and mangroves to spatially respond to SLR is still considered inconclusive and site-specific (Spalding et al., 2014).

Strengthening AR5's findings, additional empirical evidence has been published demonstrating the effects of species' range shifts and habitat phase shifts-or the transformation of a habitat into an alternative state as a result of environmental pressures-on the structure, functionality, and health of marine ecosystems and the socioeconomic sectors that depend on them. For instance, the tropicalization of temperate marine ecosystems through poleward range shifts of tropical fish grazers has been shown to increase the grazing rate on temperate macroalgae, such as those in Japan and the Mediterranean, with similar trophic impacts expected to affect ecosystem structure in temperate reefs (Vergés et al., 2014a). Similarly, a heat wave event in western Australia altered biodiversity patterns of temperate seaweeds (90\% dieback), invertebrates, and demersal fish, leading to a tropicalization of community structure (Thomson et al., 2014). The sensitivity of species' responses to ocean warming through range shifts can be affected by ecosystem status: for example, increased reef community resilience to tropicalization has been observed through protection from fishing (Bates et al., 2013). Thus, not only do phase shifts alter the availability of targeted species to fisheries, but fisheries can also play a synergistic role in reducing the resilience of ecosystems to climate change. As projected by Wong et al. (2014), temperature-mediated herbivory has since been shown to prevent kelp ecosystems from recovering from climatic drivers (e.g., effect of overgrazing of kelp beds in southern Japan (Vergés et al., 2014a); tropical herbivores preventing re-growth of kelp in Western Australia (Bennett et al., 2015); herbivorous tropical rabbitfish converting macroalgal 
forests into barrens in the Mediterranean (Vergés et al., 2014b). Phase shifts have also been documented in polar regions: for example, macroalgal colonization of newly ice-free regions has recently occurred in Antarctica (Quartino et al., 2013), and bluefin tuna have been found in the waters east of Greenland, having shifted northwards in response to warmer temperatures and to follow the northward shift of important prey species (MacKenzie et al., 2014).

\section{Projected Impacts on Fisheries' Yield, Catch Quality, and Composition}

New evidence suggests that range shifts can significantly alter the availability and composition of commercial fisheries catches, thereby having socioeconomic implications for fisheries, markets, and consumers. In Mexico, 10 of the top 12 highest fished species-including the South American pilchard (Sardinops sagax) and Penaeus shrimp-were projected to decline in catch by 2050 under the severe climate change scenario (Sumaila et al., 2014). The observed subtropicalization of European pelagic fish communities in the North and Baltic Seas has altered the availability of economically-important species, with a shift from Atlantic herring and European sprat (1960s to 1980s) to Atlantic mackerel, Atlantic horse mackerel, European pilchard, and European anchovy (1990s onwards) in response to warming (Montero-Serra et al., 2014). In tropical regions, evidence of community phase shifts from coral-to algal- or sponge-dominated reefs has been linked to reductions in reef functionality and fisheries yield (Bell J. J. et al., 2013). Altered interspecific interactions between sympatric coastal fishes have also been observed in the Mediterranean under warmer conditions, with a cooler-water fish (e.g., rainbow wrasse, Coris julis) being displaced by a more dominant warmer-water fish (e.g., ornate wrasse, Thalassoma pavo) (Milazzo et al., 2012). These examples support the theory that there will be "winners" and "losers" under climate change, with warm-adapted species outcompeting cold-adapted species in temperate marine ecosystems, accompanied by changes in the composition of fisheries' landings. However, increased temperature has also been shown to affect the physiology and interspecific competition exhibited by Arctic fish fauna, such as the Arctic staghorn sculpin, Gymnocanthus tricuspis (Seth et al., 2013), thereby potentially altering the quality, availability, and composition of traditional foods of polar communities.

Recent research continues to improve our understanding of potential future changes in primary productivity and zooplankton composition, which are important causal links to projecting future fisheries production. Models indicate an overall reduction in global primary production of $2-13 \%$ (Bopp et al., 2013), but a lack of understanding of the drivers of interannual and multidecadal climate variation and the influence of speciesspecific responses to climate change effects increases uncertainty regarding future primary production trends (Chavez et al., 2011). Development of high-resolution, shelf-seas, lower-trophic-level ecosystem models has improved projections of NPP in areas that are most important to fisheries (Barange et al., 2014). Moreover, an increasing number of Earth System Models with ocean biogeochemical components explicitly include zooplankton in their model structures, thereby providing projections of future changes in zooplankton production (e.g., Stock et al., 2014), which influences fisheries yield. Importantly synergistic effects have been found to alter projected outcomes: for example, despite individual stressors leading to declines in production, a combination of increased temperature and nutrient loads was shown to increase zooplankton production and food web efficiency in a microcosm experiment conducted in Baltic Sea conditions (Lefébure et al., 2013). However, despite these recent developments, the projected outcomes of synergistic effects on productivity are still supported by experimental evidence.

Studies continue to advance our understanding of how species' body sizes are likely to change under climate change, as supported by simulations of phase shifts between ecosystems (Ainsworth and Mumby, 2014) and by projections of climate-related impacts on ecophysiology through reduced oxygen availability (Cheung et al., 2013b). In a global model of pelagic communities, maximum body size and biomass were found to increase at high latitudes and to strongly decrease at low- to mid-latitudes in response to changes in the availability of food necessary to support metabolic requirements (Lefort et al., 2014), which agrees with previous projections. Such changes are likely to affect commercial fisheries through a reduction in the mean size of landed fish. For instance, empirical evidence of reductions in body sizes has been found for six of eight commercial fish species over a 40-year period in the North Sea, which coincided with a $1-2^{\circ} \mathrm{C}$ increase in water temperature and resulted in a $23 \%$ reduction of the mean yield-per-recruit (Baudron et al., 2014). A reduced supply of nutrients resulting from greater stratification may also yield a reduction in the average size of phytoplankton and increase the number of trophic links within food webs, which in turn would reduce energy transfer efficiency (Bell J. D. et al., 2013).

Recent studies have strengthened evidence that ocean acidification has a significant negative effect on the survival, calcification, growth, development and abundance of marine taxa (Kroeker et al., 2013), and interacts synergistically with increased temperatures to reduce species tolerance (Wittmann and Pörtner, 2013). However, recent research has shown that species' resilience to ocean acidification varies considerably across species (Range et al., 2013) and functional groups (Branch et al., 2013), with variable responses to synergistic factors. For instance, resilience to the synergistic impacts of ocean warming and acidification has been observed among juvenile sea urchins, yet conditions leading to shorter and weaker spines suggest increased vulnerability to predation (Wolfe et al., 2013). Research on species targeted by commercial fisheries-specifically, spider crabs (Hyas araneus), northern shrimp (Pandalus borealis), Antarctic krill (Euphausia superba), and European lobsters (Homarus gammarus) - suggests that crustaceans may be less severely impacted than molluscs by exposure to higher concentrations of $\mathrm{CO}_{2}$ (Branch et al., 2013). Complex relationships arising from modeled food web responses to ocean acidification suggest that trophic cascades and contradictory effects are likely to arise from changes in predatorprey dynamics: for example, projected declines in copepod abundance in Puget Sound yield increases in microzooplankton (prey) and decreases in herring (predator) abundance, yet 
reduced macrozooplankton and euphausiid biomass release some pressure on copepods and, in turn, benefit herring (Busch et al., 2013). Acidification-induced changes in the flow of energy through, and dynamics of, food webs thereby illustrate the importance of key groups (e.g., copepods) to ecosystem structure and function (Busch et al., 2013), and to ensuring the availability of key commercial fisheries stocks (e.g., herring).

New studies continue to indicate that oxygen-depleted hypoxic conditions are a major global environmental issue influenced by anthropogenic and climatic drivers, with particular relevance to tropical and temperate coastal ecosystems and sectors (Bauer et al., 2013). Time-series observations in the Atlantic, Pacific, and Indian Oceans have shown declining oxygen levels since the 1950s (Keeling et al., 2010; Gilly et al., 2013). Studies indicate that the expansion of extreme oxygen minimum zones (eOMZs) in some regions may lead to habitat compression and reduced abundance of species of pelagic and mesopelagic fish and zooplankton with low hypoxic tolerances. Recent research has diverged from existing projections of expanding OMZs, arguing that a weakening of equatorial Pacific winds may lead to a contraction of anoxic conditions in the North Pacific despite the potential for a global, stratificationdriven decline in $\mathrm{O}_{2}$ supply (Deutsch et al., 2014). This global reduction in oxygen supply is expected to exacerbate reductions in the mean body sizes of fishes under warmer temperatures (Cheung et al., 2013a), thereby detrimentally affecting the quality and mean biomass of fisheries' yield. However, new opportunities for fisheries may arise from an increased abundance of hypoxiatolerant organisms, which have also been shown to alter predatorprey dynamics and provide food for commercially-important species (e.g., Salvanes et al., 2015).

As reported in AR5, future changes in upwelling systems and the ramifications for fisheries' yields remain uncertain (Pörtner H. O. et al., 2014), but studies have contributed increasingly to strengthening our understanding of regional differences (de Lavergne et al., 2014; Sydeman et al., 2014). Stratification is projected to increase across most of the tropical Pacific, with synergistic interactions between temperature and salinity reinforcing stratification in the areas around the Pacific Warm Pool, South Pacific Convergence Zone (SPCZ), and intertropical converge zone (ITCZ) (Ganachaud et al., 2012). Ensemble projections obtained from 36 of the models from the fifth Coupled Model Intercomparison Project (CMIP5) support these projections, suggesting a weakening of deep Southern Ocean convection associated with surface freshening and stratification under climate change, which in turn may reduce the production rate of Antarctic Bottom Waters and alter ocean heat and carbon storage processes (de Lavergne et al., 2014). In contrast, a recent meta-analysis of 22 studies of eastern-boundary regions shows that upwelling-favorable winds have intensified in the California, Benguela, and Humboldt systems but weakened in the Iberian system in the past decades (up to 60 years), with the intensity of change consistent with warming pattern (Sydeman et al., 2014). This provides evidence to support the hypothesis of upwelling intensification in eastern boundary upwelling systems under climate change, which could lead to an enhanced nutrient supply in subtropical euphotic zones and a potential increase in fisheries production or, alternatively, to an increase in acidic and hypoxic conditions in shelf habitats (Sydeman et al., 2014), which could detrimentally impact species sensitive to these parameters.

In addition to changes in yield, the quality of fish stocks may be detrimentally affected by increased occurrence of disease transfer and cumulative mortality under warmer temperatures. For instance, diseases such as ichthyophous (ichthyophoniasis) reduce the market value of finfishes, thereby having wide-ranging and significant economic and ecological impacts (Burge et al., 2014). Likewise, the loss of keystone predators through disease, such as the dramatic die-off of sea stars along the Pacific coast of North America from a newly-identified densovirus (Hewson et al., 2014), can dramatically change ecosystems (Feehan and Scheibling, 2014) and, in turn, the composition and quantity of fisheries yield.

\section{Regional Impacts on Fisheries}

Studies continue to emphasize the vulnerability of tropical (Barange et al., 2014) and polar marine ecosystems (Clark et al., 2013) to climate change, with projected risks borne by the developing nations and communities that depend upon marine and coastal resources for food and economic security (Barange et al., 2014). Recent projections suggest that ecosystems at higher latitudes will generally experience increases in primary production, while those at lower latitudes are likely to experience decreases (Barange et al., 2014). However, evidence of community phase shifts arising from climate-related drivers has been found for most regions, including tropical (Inoue et al., 2013; Ainsworth and Mumby, 2014), temperate ecosystems (Wernberg et al., 2012; Thomson et al., 2014; Vergés et al., 2014a), and polar ecosystems (Quartino et al., 2013).

\section{Tropical fisheries}

The biophysical impacts of climate change and ocean acidification on tropical marine ecosystems, with particular attention to coral reefs, were addressed with great detail in AR5 (Gattuso et al., 2014b). In particular, AR5 expressed high confidence that warming and acidification would lead to coral bleaching, mortality and decreased constructional ability, indicating that coral reefs were therefore the most vulnerable ecosystem to ocean warming and acidification, with little scope for adaptation (Wong et al., 2014). Having reached general consensus regarding the impacts of individual climate-related drivers on coral reefs (Chan and Connolly, 2012; Ateweberhan et al., 2013), studies have since sought to understand the synergistic effects of multiple stressors on coral reef resilience (Mumby et al., 2013; Ban et al., 2014; McClanahan et al., 2014) and the processes that influence reef adaptation and recovery (Dixson et al., 2014; Palumbi et al., 2014; Roff et al., 2014).

Studies have now discovered that some species of coral have the capacity to acquire heat resistance through acclimatization (Palumbi et al., 2014) and to recover from bleaching events (Roff et al., 2014). For example, changes in symbiotic communities from stress-sensitive to stress-tolerant symbionts following bleaching events can lead to increased thermo-tolerance among corals (Silverstein et al., 2014). This has been supported by modeling studies that have indicated that some adaptive 
responses have already resulted in higher thermal tolerances in some corals (Logan et al., 2013). Recent studies have also suggested that biogeochemical responses of coral reef communities to ocean acidification could partially offset changes in seawater $\mathrm{pH}(12-24 \%)$ and the aragonite saturation state (15-31\%) (Andersson et al., 2013). In other cases, biofilminduced larval settlement for coral reef sponges was found to exhibit higher settlement success among biofilm communities developed at higher seawater temperatures (e.g., Rhopaloeides odorabile in the Great Barrier Reef), suggesting groups that may be more resilient to increased temperatures under climate change (Whalan and Webster, 2014).

However, the capacity for recovery or adaptation has been shown to be less certain if multiple anthropogenic and environmental stressors act in concert (Palumbi et al., 2014), with taxon-specific responses (Whalan and Webster, 2014). For instance, changes in water quality through nutrient loading and sedimentation can increase the severity of coral disease and bleaching (Vega Thurber et al., 2013), while improved water quality management can aid reef resilience and recovery (Gurney et al., 2013). Ocean acidification can also decrease calcification and increase reef erosion, making reefs increasingly susceptible to storm damage and SLR (Silbiger et al., 2014). Scientists have noted that observed changes in net ecosystem calcification could, in fact, be primarily due to increased dissolution of $\mathrm{CaCO}_{3}$ rather than decreased calcification (Eyre et al., 2014). Other documented responses have noted that cumulative impacts of repeated bleaching events could lead corals with little or no phenotypic plasticity to become increasingly sensitive to bleaching, with responses to singular bleaching events being insufficient to gauge subsequent resilience (Grottoli et al., 2014). The inclusion of such adaptive responses (e.g., directional genetic selection, symbiont shuffling) and management strategies in models is important for accurately predicting how ocean warming and acidification may affect coral reefs, with one such example reducing the frequency of mass bleaching events by $20-$ $80 \%$ (scenario-dependent) by 2100 , compared with "no adaptive response" projections (Logan et al., 2013).

The accompanying impacts on tropical coastal communities and fisheries have increasingly been explored, with evidence supporting AR5's hypothesis that there will be "winners" and "losers" under climate change. AR5 estimated that a reduction in coral cover and associated fisheries production would likely lead to net revenue losses as early as 2015 in the Caribbean (Wong et al., 2014), and projections have since suggested that greater instances of declines in fisheries catch potential are likely to occur in tropical regions (Barange et al., 2014). Modeled estimates suggest that the diversity of exploited species is likely to decrease under both RCP 8.5 and 2.6 due to a decrease in habitat suitability, with the magnitude of the decline positively correlating with the level of emissions (Jones and Cheung, 2015). There are likely to be variable impacts within tropical regions: for example, eastward range shifts in response to climaterelated drivers are expected for skipjack tuna by 2050, leading to increased catches for Pacific Island countries to the east of $170^{\circ} \mathrm{E}$ and decreased catches for those to the west (Bell J. D. et al., 2013). Fewer catches in the western EEZs of Papua New Guinea
$(-11 \%)$ and the Solomon Islands $(-5 \%)$ are expected to translate to a 0.1 to $0.4 \%$ decline in GDP because of the large size of their economies (Bell J. et al., 2013). In Bangladesh, prawn postlarvae fishers have been impacted indirectly by increased intrusion of saline water into agricultural land, which has increased fishing pressure from displaced farmers, while climate-related drivers have and are expected to lead to a net loss in revenue, food security, and livelihood sustainability (Ahmed et al., 2013).

Marine taxa in tropical regions are also likely to lose critical habitats such as coral reefs, mangroves, and seagrasses through phase shifts toward other habitats (e.g., macroalgae; Kroeker et al., 2012; Ainsworth and Mumby, 2014), with corresponding declines in fisheries productivity (Bell J. D. et al., 2013). While phase shifts could lead to new or increased fishing opportunities, such as increased shrimp biomass and landings through a reduction in carnivorous macrobenthos, it is likely that local communities will need to abandon traditional harvests in lieu of less valuable but more abundant species (Ainsworth and Mumby, 2014). Reduced fitness of commercially important species, such as coral trout (Plectropomus leopardus; Johansen et al., 2013), could also have implications for the sustainability of coral reef fisheries.

The interdependence between different tropical marine habitats has been highlighted recently, suggesting cascading effects across ecosystems through habitat loss (Saunders et al., 2014). Coastal vegetative habitats such as seagrasses function as nurseries for the early life-stages of reef fishes and are, in turn, sheltered from incoming waves by coral reefs (Saunders et al., 2014). This suggests that a climate- and $\mathrm{CO}_{2}$ - driven loss of coral reefs or other critical habitats may therefore have large-scale implications across ecosystems (Saunders et al., 2014) and the sectors that depend on them. The importance of coastal lagoon ecosystems to fishing, aquaculture, tourism, and industrial sectors, particularly within the Mediterranean Sea, demonstrates how biophysical changes could yield detrimental socioeconomic impacts across sectors, thereby reducing local food and economic security (Marques et al., 2014).

\section{Temperate and subtropical fisheries}

Overfishing has been shown to be the major driver of catch declines in heavily exploited ecosystems globally (Pauly and Zeller, 2016), although warming-driven changes in species composition are also affecting fisheries (Pinsky and Fogarty, 2012; Cheung et al., 2013b). For instance, total catch decline in the Mediterranean has been primarily linked to overexploitation (Vasilakopoulos et al., 2014; Tsikliras et al., 2015), with fewer instances of changes in the abundance of individual species having been linked primarily to changes in climate (Milazzo et al., 2012; Teixeira et al., 2014; Gamito et al., 2015).

Moving forward, anthropogenic pressures such as these are likely to be exacerbated under climate change, with climateinduced declines in catch projected for fisheries in the Northeast Pacific (Ainsworth et al., 2011; Barange et al., 2014), Northwest Atlantic (20-22\% declines; (Guenette et al., 2014), and Northeast Atlantic $(8.3 \%$ decrease in maximum catch potential; (Jones et al., 2014). An ecosystem-based assessment of synergistic climate change effects on the Nova Scotian shelf of eastern 
Canada projected a $19 \%$ (optimistic scenario) to $29 \%$ (pessimistic scenario) reduction in biomass with accompanying declines in fisheries catch potential ( -20 to $22 \%$, respectively; Guenette et al., 2014). Likewise, declines in seafloor biomass have been projected for more than $80 \%$ of deep-sea biodiversity hotspots around the world by the end of the century (2091-2100), with up to a $38 \%$ decrease in benthic biomass in parts of the Northeast Atlantic (Jones et al., 2013).

Over the last few years, studies have demonstrated the link between sea surface temperatures (SST) and fisheries landings in temperate and subtropical regions (Tzanatos et al., 2013; Teixeira et al., 2014; Gamito et al., 2015). Portuguese fisheries have experienced declines in landings of temperate fish and increased landings of subtropical and tropical species between 1970 and 2011, which have been statistically linked to changes in SST; since the latter species are often of greater commercial importance, increased SST under climate change may offer opportunities for fishers in the Mediterranean (Teixeira et al., 2014). Conversely, culturally-important sponge fisheries in the Mediterranean Sea have been threatened by climatic and anthropogenic stressors such as ocean warming, overfishing, and species invasions (Pérez and Vacelet, 2014), all of which are likely to continue under climate change. Likewise, the loss of economically valuable and endangered corals as a result of ocean acidification could lead to considerable losses in revenue, with values of 230-300 US\$ $\mathrm{kg}^{-1}$ for thin juvenile branches of red coral (Corallium rubrum) and up to 50,000 US $\$ \mathrm{~kg}^{-1}$ for Pacific Corallium sp. colonies with a diameter greater than $4 \mathrm{~cm}$ (Bramanti et al., 2013).

A recent study projected that climate-induced changes in relative environmental suitability and fisheries catch potential would translate to a $10 \%$ loss in net present value within the UK's exclusive economic zone by 2050, without accounting for the additional fuel and gear costs that might be incurred (Jones et al., 2014). Economic impacts are also likely to extend to seaports where fisheries' landings are taken through increased maintenance costs associated with corrosion from ocean acidification, disruption of transport, and damage to infrastructure through storm surges, SLR, and flooding (Becker et al., 2013; Nursey-Bray et al., 2013).

\section{Polar Fisheries}

Discernible impacts attributed to climate change have been recorded in polar marine ecosystems, but studies evaluating these impacts remain scarce and primarily focus on species of economic importance, such as cod and shrimp, or on marine mammals (Wassmann et al., 2011; McBride et al., 2014). Recently, polar ecosystems and corresponding fisheries have experienced a marine "Klondike," or the expansion of industrial exploration polewards in response to a reduction in the spatial extent of sea ice, with industrial fisheries and aquaculture alike increasingly finding new commercial opportunities at higher latitudes (Christiansen et al., 2013). Moving forward, declines in the temporal and spatial extent of sea ice cover are likely to provide finfish fisheries with greater access to stocks, thereby offering new opportunities (Constable et al., 2014). In particular, the Antarctic krill fishery has been suggested as a significant opportunity for expansion under climate change through changes in sea-ice extent, but the opportunities and losses with respect to this fishery remain ambiguous (Constable et al., 2014). For instance, projections have suggested that climate change could have a negative effect on Antarctic krill growth habitat (Hill et al., 2013), with krill embryos and larvae exhibiting enhanced energetic requirements and delayed development in response to elevated $\mathrm{CO}_{2}$ levels (Kawaguchi et al., 2013). Likewise, while recent observations suggest that invertebrate species may be invading deep-sea and benthic habitats in the Southern Ocean, the potential for highly productive pelagic finfish to invade this region appears low due to minimal projected changes in the thermal gradient (McBride et al., 2014). However, the opening of trans-Arctic trade routes through reduced sea ice cover has been discussed as a potential driver of species invasions through ship-mediated transport and natural dispersal, which will likely alter the dynamics and structure of Arctic ecosystems (Ware et al., 2013; Miller and Ruiz, 2014). To date, there is accumulating evidence of species that have shifted into polar regions in response to warmer temperatures (Astthorsson et al., 2012; MacKenzie et al., 2014),

Recent studies project that a loss of critical habitat, including sea ice, is likely to lead to an increase in genetic connectivity and disease transfer between previously isolated populations of marine fauna (Post et al., 2013; Wisz et al., 2015), while a longer open-water season through decreased sea-ice cover could increase coastal erosion and storm impacts (Barnhart et al., 2014). A recent study projected an Atlantic-Pacific fish interchange, with up to 41 species entering the Pacific and 44 species entering the Atlantic by 2100 via the Northwest and Northeast Passages (Wisz et al., 2015). This interchange would alter the composition and predator-prey dynamics of ecosystems, with corresponding changes to existing fisheries yields and potential new opportunities within the Northwest Passage (Wisz et al., 2015). Recent research has also provided new insight regarding the susceptibility of polar marine ecosystems to light-driven tipping points emerging from changes in ice loss and solar irradiance. Areas without ice and snow following the summer solstice are particularly vulnerable to abrupt changes resulting from increased solar exposure through earlier ice loss; for this reason, future ice loss could lead to autotroph-dominated polar ecosystems with higher productivity, but lower regional biodiversity (Clark et al., 2013).

The geopolitical consequences associated with an increasingly ice-free Arctic are of critical concern not only with respect to maintaining the ecological structure and function of polar ecosystems, but also to the local communities that depend on marine resources for a range of ecosystem services (Christiansen et al., 2013). Increased marine access through sea-ice loss is likely to lead to increased industrial development, resource extraction, and shipping opportunities (Miller and Ruiz, 2014), with the accessibility of near-coastal and remote marine zones of all eight Arctic nations anticipated to increase by up to $28 \%$ by 2050 (Post et al., 2013).

Small-scale fishing communities in polar regions are likely to be detrimentally affected by temperature- and $\mathrm{pH}$-induced changes in fisheries due to a large dependence on local harvests for food and economic security (AMAP, 2013). However, 
community-based assessments of socioeconomic impacts on rural and Indigenous coastal populations risk undervaluing the importance of marine harvests to Arctic cultures given their role in forming cultural identity and providing essential nutritional requirements (AMAP, 2013). Thus, while the broad range of species harvested by indigenous communities offers opportunities for adaptation through alternative harvests, they may be accompanied by seasonal or cultural losses (AMAP, 2013). Moreover, despite the projected increases in the relative abundance of fish stocks, increased competition over new resources and reduced availability of traditionally harvested species may severely inhibit fishing opportunities, while limited management offers few precautionary controls to ensure sustainable fisheries management under climate change (AMAP, 2013; Lam et al., 2014). Moreover, the growing presence of industrial fisheries under climate change may lead to intensified bottom trawling and unprecedented bycatch, affecting ecosystem function and structure and the availability of indigenous peoples' traditional foods (Christiansen et al., 2013).

A recent estimate projected that total fisheries revenue in the Arctic region may increase by 39\% (14-59\%) by 2050 relative to 2000 under the Special Reports on Emission Scenario (SRES) A2, while ocean acidification is expected to reduce the potential increases in fisheries catch and revenues (Lam et al., 2014). On the other hand, while increased anthropogenic activity in the Arctic has been linked to economic opportunities and ecological concerns (Larsen et al., 2014), Whiteman et al. (2013) argue that the global economic implications associated with climatic change in the Arctic have been ignored. For instance, the release of methane from thawing permafrost off northern Russia alone has been valued at $\$ 60$ trillion in the absence of mitigation (Whiteman et al., 2013). After accounting for global changes in sea level, economic and non-economic sectors, and the melting of ice sheets, the mean projected cost of climate-related impacts fell between $\$ 82$ trillion ("low-emissions" scenario) and $\$ 400$ trillion ("business-as-usual" scenario), of which the majority of the projected cost $(80 \%)$ is expected to be borne by developing nations in Africa, Asia and South America (Whiteman et al., 2013).

\section{Aquaculture \\ Projected Impacts on Future Shellfish and Fish Aquaculture Production}

Aquaculture production formed 90.4 million tonnes, (live weight equivalent) as of 2012, contributing approximately US $\$ 144.4$ billion to the global economy in food products and an additional US $\$ 222.4$ million in non-food products, such as pearls and seashells (FAO, 2014). While few studies have provided quantitative estimates of economic impacts associated with climate-induced changes in aquaculture production, studies have offered assessments of the likelihood of regional losses or gains.

Climate- and acidification-related impacts on aquaculture are expected to vary by location, species, and method of aquaculture. Latitudinal and taxon-specific trends have been identified, with the farming of higher trophic level species (e.g., trout farming in northern Mediterranean countries) expected to exhibit higher mortality rates and lower productivity under warming (Rosa et al., 2014). Conversely, inland production in southern countries tends to be based on more resilient species (e.g., carp and tilapia farming in Egypt), and may therefore experience increased metabolic rates, growth rates, and overall production (Rosa et al., 2014). The projected resilience of freshwater species is attributed to faster growth rates associated with warming and an increase in the availability of freshwater through increased precipitation (Bell J. D. et al., 2013).

Despite the capacity to control for conditions, recent studies suggest that aquaculture is likely to be both negatively and positively affected by changes in precipitation, temperature, drought, storms, and floods, all of which would have socioeconomic implications (Bell J. D. et al., 2013; FAO, 2014; Li et al., 2014). For instance, aquaculture facilities in the Caribbean and Latin American regions are likely to be vulnerable to ocean acidification and extreme weather events, with the potential for flooding in the Caribbean to affect local facilities (FAO, 2014). Similarly, the economically valuable black pearl industry in Polynesia is expected to be vulnerable to increased SST and ocean acidification, which-given its role in employing thousands of people on remote atolls-is expected to lead to a loss in local revenue and employment (Bell J. D. et al., 2013).

SLR is further expected to impact aquaculture production through increased intrusion of saline water into deltas and estuaries, where aquaculture commonly occurs (e.g., Mekong and Red River deltas in Viet Nam and the Ganges-Brahamputra Delta in Bangladesh) (De Silva, 2012). In Bangladesh, where fish cultivation and agriculture are the main occupations in coastal regions, fish cultivators have already reported production problems associated with increased salinity and disease prevalence (Garai, 2014). As the greatest producers of aquaculture, small-scale Asian practices in coastal bays are at high risk from storms, wave surges, and high winds, with the potential for significant losses for local livelihoods (De Silva, 2012). Li et al. (2014) estimated both positive and negative economic impacts for Chinese aquaculture, with lower latitudes likely to experience predominantly negative impacts as a result of increased water temperatures and reduced primary production, leading to significant impacts on food security and employment. In particular, increased precipitation yielded significant benefits to profit, while increased weather variability was associated with lower profit, highlighting the sensitivity of aquaculture production to sudden, extreme weather events (Li et al., 2014). However, these impacts may be reduced by selecting more salinetolerant and brackish-water species for aquaculture operations (Rosa et al., 2014).

The increased threat of infectious disease to aquaculture under climate change has been explored more recently, with shellfish larval dispersal having been implicated in the transport of disease (Rowley et al., 2014). The susceptibility of molluscs and crabs to diseases such as vibriosis has been linked to SST, and temperature-driven poleward range shifts are expected from an influx of new pathogens in temperate regions (Rowley et al., 2014). These may pose an increased threat to human health through the consumption of contaminated seafood and waterborne pathogens (Rosa et al., 2014). The toxicity of common pollutants to fish can increase with higher temperatures, while 
a decrease in salinity has been shown to increase toxicity for some species by altering the chemical speciation of metals (Fabbri and Dinelli, 2014). As reported in AR5, studies have continued to warn that increased ocean temperatures and eutrophication under climate change may lead to a greater occurrence of toxic tides, such as more frequent HABs in the Mediterranean Sea, and thereby detrimentally affect aquaculture production and human health (Himes-Cornell et al., 2013; Rosa et al., 2014). From a global perspective, cumulative mortality from disease was found to be relatively higher in tropical aquaculture than in temperate aquaculture ( 88 vs. $34 \%$, respectively), with juvenile invertebrates exhibiting greater vulnerability in comparison with adult finfish (Leung and Bates, 2013). This evidence highlights a management concern for developing nations at subtropical and tropical latitudes that would otherwise benefit from increased food security through aquaculture.

Overall, with decreased dependence on wild-caught stocks for fishmeal and farming combined with technological developments, recent research suggests that aquaculture could significantly contribute to global food security under climate change (Barange et al., 2014), but highlights the tradeoffs between coastal sectors that are likely to occur (Ruckelshaus et al., 2013). Longer growing seasons, faster growth rates, and lower winter mortality arising from increased temperatures could yield positive effects at mid- to high-latitudes (e.g., extended breeding periods for Indian carps in fish farm hatcheries in West Bengal; De Silva, 2012; Li et al., 2014). However, trade-offs are expected to occur as aquaculture industries compete with other sectors (e.g., wild-caught fisheries, coastal tourism) for different ecosystem services derived from coastal and wetland habitats that are sensitive to climate change (Ruckelshaus et al., 2013), and tropical and subtropical aquaculture may encounter challenges associated with SLR and an increased risk of disease susceptibility.

\section{Coastal Tourism and Local Economies}

Tourism is one of the largest sectors in the global economy, with coastal tourism comprising a significant part of global revenue derived from the tourism sector. Climate-induced impacts on tourism have considerable ramifications for local, national, and regional economies, including the transportation, fishing, and agricultural sectors. Drivers such as ocean warming and acidification are likely to lead to changes in SST, the composition and abundance of marine biodiversity, and sea levels (Pörtner H. O. et al., 2014; Howes et al., 2015). In addition, extreme and abrupt climatic events such as storms and cyclones will impact coastal environments and communities. Collectively, these drivers will lead to changes in the basic conditions for coastal tourism, including climatic parameters (air temperature, precipitations, wind speed, etc.), underwater parameters (SST, invasive species such as jellyfishes, etc.), and coastal hazards (erosion, marine flooding, etc.). Such changes will affect the main components of the tourism industry-such as tourists' preferences, tourism operators' strategies, and the transportation market-and thus the tourism supply and demand balance at the global scale.

\section{Ocean Warming and Acidification Impacts on Tourism Flows}

As documented in AR5, changes in the quality and abundance of coral reef cover are expected to cause socio-economic and environmental concerns for small island developing states (SIDS) and developing countries, with particular relevance to the tropics (Wong et al., 2014). Coral reefs draw significant tourism each year, supporting recreational activities, such as diving and snorkeling, and supporting coastal communities and auxiliary sectors.

Tropical coastal areas are unlikely to be the only areas affected. In Europe, Spain's coastal tourism is expected to face water shortages, reduced opportunities for different tourism modalities, and, in turn, fewer job opportunities in the tourism industry (Saurí et al., 2013). In particular, new findings suggest that there may be "winners" and "losers" in coastal tourism as a result of higher temperatures that discourage southward tourism flows in Europe while reinforcing northwards flows (DiSegni and Shechter, 2014).

Recent studies provide additional evidence that species range shifts are likely to alter tourism flows. For instance, poleward range shifts in the United States could yield new opportunities for recreational fishing in temperate regions, while warmer conditions could benefit some species purposively introduced for recreational fishing (Nelson et al., 2013). Conversely, increases in the prevalence of tropical box jellyfish through climateinduced poleward range shifts could detrimentally affect coastal tourism and water-related activities in subtropical and temperate regions. In particular, a recent study found that irukandjii jellyfish (Alatina $\mathrm{nr}$ mordens) polyps were resilient to the combined effects of ocean acidification and warming, suggesting that these polyps would be able to colonize new areas under climate change and thereby increase socioeconomic losses and hospitalization events (Klein et al., 2013). Increased prevalence and transmission of diseases are also likely to occur under warmer ocean temperatures, with empirical evidence of poleward shifts in disease outbreaks under warmer conditions (Burge et al., 2014). Importantly, adverse publicity accompanying an increased risk of disease transmission in tropical and subtropical regions could further have deleterious impacts on coastal tourism (DiSegni and Shechter, 2014).

\section{Impact of Ocean Warming and Acidification on Tourism Operators' Infrastructure, Strategies, and Revenue}

Key impacts arising from warming and SLR are likely to include degradation of coastal infrastructure through coastal erosion, marine flooding, high winds, and/or inundation of rivers, as well as changes in the attractiveness of destinations due to changes in air and sea temperatures, landscapes, and swimming conditions. Coastal flooding is increasingly a concern both for developed and developing cities, with coastal populations expected to grow by $25 \%$ by 2050 (Aerts et al., 2014).

Ocean warming and acidification is therefore expected to not only affect tourism in SIDS and developing countries, but also in developed areas such as Europe and the United States. Consequently, the economic implications of coastal tourism are 
expected to be significant for most of the destinations around the world, and especially at the local scale. In the United States, 7.52 million jobs and $\$ 1.11$ trillion in sales are supported by tourism, with the majority of tourism occurring in coastal regions that are expected to experience changes in weather conditions and extreme events, such as typhoons and hurricanes (Himes-Cornell et al., 2013). Beach recreation values are also expected to decline in response to narrower beaches resulting from SLR and erosion, with considerable losses for local economies (e.g., \$1 billion loss between 2006 and 2080 in North Carolina Whitehead et al., 2009; Nelson et al., 2013). As principal assets of coastal tourism, the loss of beaches could significantly impact local economies in subtropical and topical regions, and could incur additional costs associated with coastal protection and infrastructure repairs (DiSegni and Shechter, 2014).

\section{Human Health and Food Security}

Knowledge regarding the impacts of climate change on human health in coastal regions has departed little from that outlined in AR5 (Pörtner H. O. et al., 2014; Wong et al., 2014). While the future consequences of ocean warming and acidification on food security derived from aquaculture and capture fisheries are difficult to estimate (Portner J. R. et al., 2014), regional trends illustrate the particular vulnerability of developing nations and the rural and indigenous communities that depend on tropical and polar marine ecosystems for food security (Larsen et al., 2014; Portner J. R. et al., 2014; Pörtner H. O. et al., 2014).

Declines in fisheries catch potential are expected to detrimentally impact food security in tropical nationspredominantly those in South and Southeast Asia and SIDS—through reduced access to nutrition (Barange et al., 2014), while recent studies suggest that competition over resources and ocean acidification may offset some of the gains in fisheries catch potential projected for polar regions (Lam et al., 2014; Larsen et al., 2014; Miller and Ruiz, 2014). For instance, a 20\% reduction in coral reef fish production by 2050 is expected to detrimentally affect food security for Pacific Islanders, with even well-managed fisheries failing to meet nutritional requirements of a growing population (Bell J. D. et al., 2013). Recent shifts in anchovy and sardine regimes in the Pacific Ocean also demonstrate altered patterns of food availability (Wheeler and von Braun, 2013). However, while acidification and warming-related declines in fisheries productivity in South and Southeast Asia are expected to reduce food security, opportunities have been identified through the regions' growing aquaculture production (Barange et al., 2014). Although range shifts have been projected to increase the availability of fish stocks in polar regions, these projections are uncertain (AMAP, 2013; Larsen et al., 2014), and studies have suggested that ocean acidification and increased competition arising from increased accessibility through reduced ice cover (Lam et al., 2014; Miller and Ruiz, 2014). Likewise, SLR is expected to increase the risk of loss of agricultural land in coastal regions through flooding, with further detriment to food security (Wheeler and von Braun, 2013).

Recent research has demonstrated that Indigenous fishing communities that depend on traditional marine resources for food and economic security are particularly vulnerable to climate change through a reduced capacity to conduct traditional harvests because of limited access to, or availability of, resources (Larsen et al., 2014; Weatherdon et al., 2016). For instance, shellfish and traditional clam beds-which form an integral part of the culture, economy and diet of many Indigenous communities situated along the Pacific Coast of North Americamay be affected detrimentally by increased SST, SLR, and changes in ocean chemistry and circulation patterns (Lynn et al., 2013). This has critical implications for the food and economic security of coastal Indigenous communities, the preservation and transfer of their traditional knowledge, and the legal upholding of their rights to access traditional resources (Lynn et al., 2013).

Hosts and parasites are likely to accompany species poleward range shifts under climate change, with disease outbreaks having been witnessed under warmer conditions (e.g., faster replication of disease among corals in the Caribbean) (Altizer et al., 2013). Such diseases can lead to community shifts and trophic cascades through the loss of habitat or keystone species (Altizer et al., 2013). For instance, Arctic warming has been projected to facilitate disease transmission between eastern and western Arctic species (Post et al., 2013). While these impacts predominantly focus on ecological systems, such changes are likely to affect human health through declines in food security (e.g., disease propagation in crops or traditional foods) and increased opportunities for pathogen transfer between hosts (Altizer et al., 2013).

Supporting AR5's findings, research continues to suggest that human exposure to diseases is likely to increase under climate change through storm surges and SLR, each leading to an expansion of the geographical and seasonal ranges of bacteria (Burge et al., 2014). For instance, a poleward range shift of outbreaks of Vibrio has been witnessed as far north as the Baltic Sea and Alaska (Burge et al., 2014). Sub-Saharan Africa is projected to experience a southern climate-induced shift in malaria incidences, while additional health concerns include food insecurity, hunger and malnutrition, natural disasters, air pollution, communicable, and non-communicable diseases, high-injury burden, mental health, and occupational health (e.g., heat stress) (Ziervogel et al., 2014). Similarly, SIDS have been framed as "canaries in the coal mine" with respect to climate change and health given their dependence on marine resources for nutrition and the prevalence of infectious diseases, each of which are expected to be affected detrimentally by climate change (Hanna and McIver, 2014). Despite these concerns, data supporting causal pathways between climatic variables and human health outcomes through marine ecosystems are still limited (Ziervogel et al., 2014).

Finally, HABs and toxins associated with climate change have continued to be identified as priority areas for research (Fleming L. E. et al., 2014). HABs are expected to increase in frequency through higher coastal eutrophication, and are likely to have detrimental effects on coastal productivity, nursery grounds, biodiversity, and human health through the consumption of contaminated seafood (Himes-Cornell et al., 2013; Marques et al., 2014). 


\section{Brief Insights on Coastal Adaptation Across Sectors \\ Adaptation in Fisheries, Aquaculture, and Auxiliary Sectors}

The capacity for fisheries to mitigate and adapt to climate change has been increasingly studied in different regional contexts. Some examples of adaptation strategies to climate change effects on fisheries include changing targeted species (e.g., Cheung et al., 2013a) and establishing multi-lateral fisheries agreements (e.g., Miller et al., 2013). In one context, three-fleet dynamic models were used to investigate the effects of climate change on the ecological, economic, and social viability of the Tasmanian rock lobster fishery in southern Australia, highlighting the importance of dynamic adaptation in response to environmental conditions and stock abundance (Hamon et al., 2013). While it remains uncertain whether small-scale fisheries will have the mobility to follow target species, those with access to multiple gears may be able to adapt more easily to climate-related changes in stock composition (Gamito et al., 2013, 2015; Teixeira et al., 2014).

Livelihood diversification continues to be supported within the literature as a viable adaptation strategy in response to reduced production in some fisheries and aquaculture operations (Bell J. D. et al., 2013; Ruckelshaus et al., 2013). For example, poleward range shifts may provide opportunities for fisheries to redirect fishing effort toward emerging fisheries; however, the capacity for fisheries to capitalize on these shifts would depend on the adaptive capacity of local economic, cultural, and regulatory institutions (Nelson et al., 2013; Ruckelshaus et al., 2013).

Adaptation options for aquaculture production have also been suggested. Livelihoods based on pearl production may be supported through deeper-water cultivation, selective breeding, and selection of suitable sites for production (Bell J. D. et al., 2013). Richards et al. (2015) concluded that aquaculture is likely to be more viable in the future than wild fisheries because of the capacity to monitor and modify conditions to avoid excessive stressors arising from ocean acidification and other climaterelated drivers. After accounting for different life stages, they further gauged that prawns would likely be more resilient to ocean acidification than scallops in Queensland, Australia, due to a greater diversity of species across a larger geographical distribution (Richards et al., 2015). The capacity for aquaculture stocks to be more resilient to climate change than wild stocks is further supported through selective breeding and vaccination, which provide means of increasing stock resilience and reducing the frequency of disease transmission (Himes-Cornell et al., 2013). Intertidal oyster reefs have also demonstrated resilience by exhibiting the capacity to outpace SLR, and can function as buffers to help preserve vegetated estuarine ecosystems and coastal structures from erosion (Rodriguez et al., 2014).

Recent studies exploring climate-related impacts on seafood supply chains have found that there is a limited understanding of how these impacts will affect other parts of the supply chain, despite a comprehensive understanding of impacts at the harvest stage (Fleming A. et al., 2014). Increased stakeholder awareness in the Australian seafood industry regarding potential impacts of climate change on supply chains has led participants to highlight adaptation options within their respective sectors, including improved fuel efficiency, breeding programs, altered industry structure, simplified regulations, and improved public awareness (Fleming A. et al., 2014).

\section{Adaptation in the Tourism Sector}

The tourism sector is sensitive to both gradual changes in climatic and oceanic conditions, and to extreme and abrupt weather events. Historically, the tourism industry has exhibited high adaptive capacity in response to shocks (e.g., financial crises, natural disasters, and disease), strongly suggesting the capacity to respond to future climate-induced variability through dynamic adaptation (Scott, 2014). For instance, recreational fishers in the Arctic appear to be willing to target alternative species, suggesting a future change in the relative composition of recreational catches under climate change (AMAP, 2013).

The capacity for stakeholders to respond to long-term changes, such as increased mean seasonal temperatures and beach erosion, is less understood. Destinations may benefit from or lose opportunities as a result of changes in observed or perceived attractiveness (Ciscar et al., 2011; Magnan et al., 2012; Arent et al., 2014). This indicates that various strategies must be evaluated when considering the diversity of tourist operators' responses, which are influenced by their level of dependence on local environmental conditions. Schematically, while it may be feasible for international companies to relocate their investments, small business owners may face limitations when endeavoring to protect local resort infrastructure. With respect to location attractiveness, a study evaluating perceptions of climate-related impacts along the Balearic coasts of Spain noted that a lack of concern indicated by citizens could lead to a higher degree of vulnerability since adaptive measures could be seen as unnecessary, and therefore not implemented (March et al., 2013). This could, in turn, affect the feasibility of coastal tourism markets given increased vulnerability of local real estate. Forecasting stakeholders' responses to ocean warming and acidification is challenging as stakeholders are not equal in terms of their risk perception, interests, and adaptive capacities, and thus they will adopt different strategies. Here again, there will inevitably be winners and losers (Arent et al., 2014), both among international tourism companies and small enterprises.

While it is very complex to forecast changes in tourists' preferences, companies' adaptation strategies, and transportation companies' responses to changes in a destination's attractiveness, models have begun to emerge in the past decade and, although encountering limitations (Arent et al., 2014), have started identifying key questions related to tourism flows, tourism operators' adaptation strategies, and economic impacts at the local scale.

\section{Ecosystem-Based Adaptation for Coastal Communities}

Adaptation strategies suggested in AR5 included the restoration or ecosystem engineering of marine vegetative habitats to assist with buffering climate-related impacts and to provide shelter for fish nurseries and important coastal habitats (Wong et al., 2014). Studies have continued to suggest the capacity for coastal ecosystems, including intertidal wetlands and reefs, to protect 
coastlines by reducing wave energy, minimizing impacts from storm surges, increasing sedimentation, and/or reducing erosion (Spalding et al., 2014).

While promising, ecosystem-based coastal adaptation approaches are still emerging, and require an improved understanding of key ecosystem services and values for coastal communities in order to assess risk, aid coastal development planning, and build decision support systems (e.g., Spalding et al., 2014). Managing realignment of coastal ecosystems as they migrate landwards or polewards can aid in proactively planning for future conditions, while hybrid engineering structures can provide an integrated way of conserving ecosystems and ecosystem services (e.g., carbon storage and sequestration; regulating nutrient fluxes; maintaining species biodiversity). This could in turn increase coastal protection (Duarte et al., 2013; Spalding et al., 2014). Proposed mechanisms for protecting these ecosystems include strategic zoning that anticipates habitat migration and minimizes climate-related impacts (e.g., Wetland Buffer Guidelines implemented by the Queensland government) and the use of predictive models to situate reserves (e.g., landscape and SLR models) (Shoo et al., 2014). Evidence that the preservation of coastal vegetative habitats and wetlands can yield a net uptake of atmospheric $\mathrm{CO}_{2}$ has continued to emerge, with examples found for boreal, temperate, and subtropical seagrasses (Tokoro et al., 2014), and agreement that coastal wetlands aid in regulating GHG emissions continues to accumulate (Ross and Adam, 2013). Importantly, recent research has suggested that the magnitude of carbon storage can vary greatly by location (i.e., depth or latitude) and species (e.g., temperate and subtropical seagrasses in coastal Australia) (Lavery et al., 2013). Given this potential to mitigate anthropogenic emissions, some authors argue that the expansion of the current REDD+ (Reducing Emissions from Deforestation and Forest Degradation) scheme to include vegetative coastal ecosystems could provide opportunities for SIDS and other developing states to mitigate climate change, while promoting restoration of coastal habitats that have been degraded or removed for development (Duarte et al., 2013).

Recent studies have also highlighted the economic feasibility of restoring and maintaining coastal habitats, which offer a costeffective measure of increasing coastal protection and ecosystem services when compared with "hard" engineering solutions, such as seawalls (Nelson et al., 2013). Coastal habitats can also yield profit for commercial and recreational activities occurring on the coast, with the potential for the benefit-to-cost ratio of such eco-engineering solutions to exceed that of "hard" solutions (Nelson et al., 2013). From another perspective, the loss of ecosystem services accompanying SLR-induced coastal erosion in Europe is estimated at $€ 2.9$ billion per year by 2050 , resulting in an almost $15 \%$ decrease in coastal ecosystem service values compared to 1975 (Roebeling et al., 2013). In South America, the coastal lagoon ecosystems in Uruguay provide a range of ecosystem services, including food, fuel and fiber, flood and storm protection, erosion control, and carbon sequestration (Fanning, 2014). In particular, climate-induced impacts on ecosystem service values in a coastal lagoon, Laguna de Rocha, were calculated for carbon sequestration services (annual revenue of
$€ 178,487$ to $€ 290,540$ between 2008 and 2011 in the Laguna de Rocha) and habitat maintenance and cultural values (damage costs avoided method yielded an inferred value of US $\$ 300,000$ between 1986 and 2012) (Fanning, 2014). Thus, maintenance of coastal habitats functions both as a cost-effective measure for protecting coastal infrastructure and as a method of preserving economically important ecosystem services.

While examples of coastal habitat recovery exist (e.g., recovery of cordgrass in New England following die-off), the capacity for habitats to fully recover to their previous state is less certain and subsequent trophic cascades can further reduce habitat resilience (e.g., loss of ribbed mussel beds in New England without cordgrass habitats, which in turn limits cordgrass production) (Brisson et al., 2014). In the context of coral reefs, Rogers et al. (2014) used a scenariobased approach to evaluate the sensitivity of 14 ecosystem services to different climate-related drivers and management strategies. While their research suggests that reserves will remain effective for reefs with high structural complexity, maximizing ecosystem services in degraded reefs would require a portfolio of management strategies (e.g., provision of artificial complexity, coral restoration, fish aggregation devices, herbivore management) (Rogers et al., 2014). Yet, it may be possible for full ecosystem services to be restored without fully recovering the original ecosystem structure (Brisson et al., 2014).

\section{AGREEMENT AND POINTS OF DEPARTURE FROM AR5}

In agreement with the findings of AR5, strong evidence continues to indicate that climate change will lead to a redistribution of benefits and losses at multiple scales, and across human and ecological systems (Barange et al., 2014). For instance, tourism flows, diseases, and species are projected to shift polewards under warmer temperatures (Magnan et al., 2012; Cheung et al., 2013a; Burge et al., 2014; DiSegni and Shechter, 2014). Latitudinal trends suggest benefits accruing in polar regions for commercial sectors (e.g., new fishing and extraction opportunities, increased shipping access) (Post et al., 2013; Miller and Ruiz, 2014), while losses are projected for tropical and subtropical regions through reductions in fisheries catch potential and reduced food and economic security (Barange et al., 2014). Ecologically, "winners" and "losers" are also expected to arise from community phase shifts and trophic cascades (Bell J. et al., 2013; Inoue et al., 2013; Ainsworth and Mumby, 2014), with some species outcompeting others under multiple stressors (Brown and Thatje, 2014) (Figure 1; Table 2).

Empirical and theoretical evidence continues to support the occurrence of climate-induced range shifts of species and coastal marine ecosystems, which were reported with very high confidence in AR5 (Pörtner H. O. et al., 2014). Shallow tropical water systems and coastal mangroves are expected to shift polewards, with species richness increasing at higher latitudes (Ross and Adam, 2013). While projections suggest the capacity for some coastal vegetative ecosystems to shift landward in response to sea level rise, adaptive capacity and growth rates may 


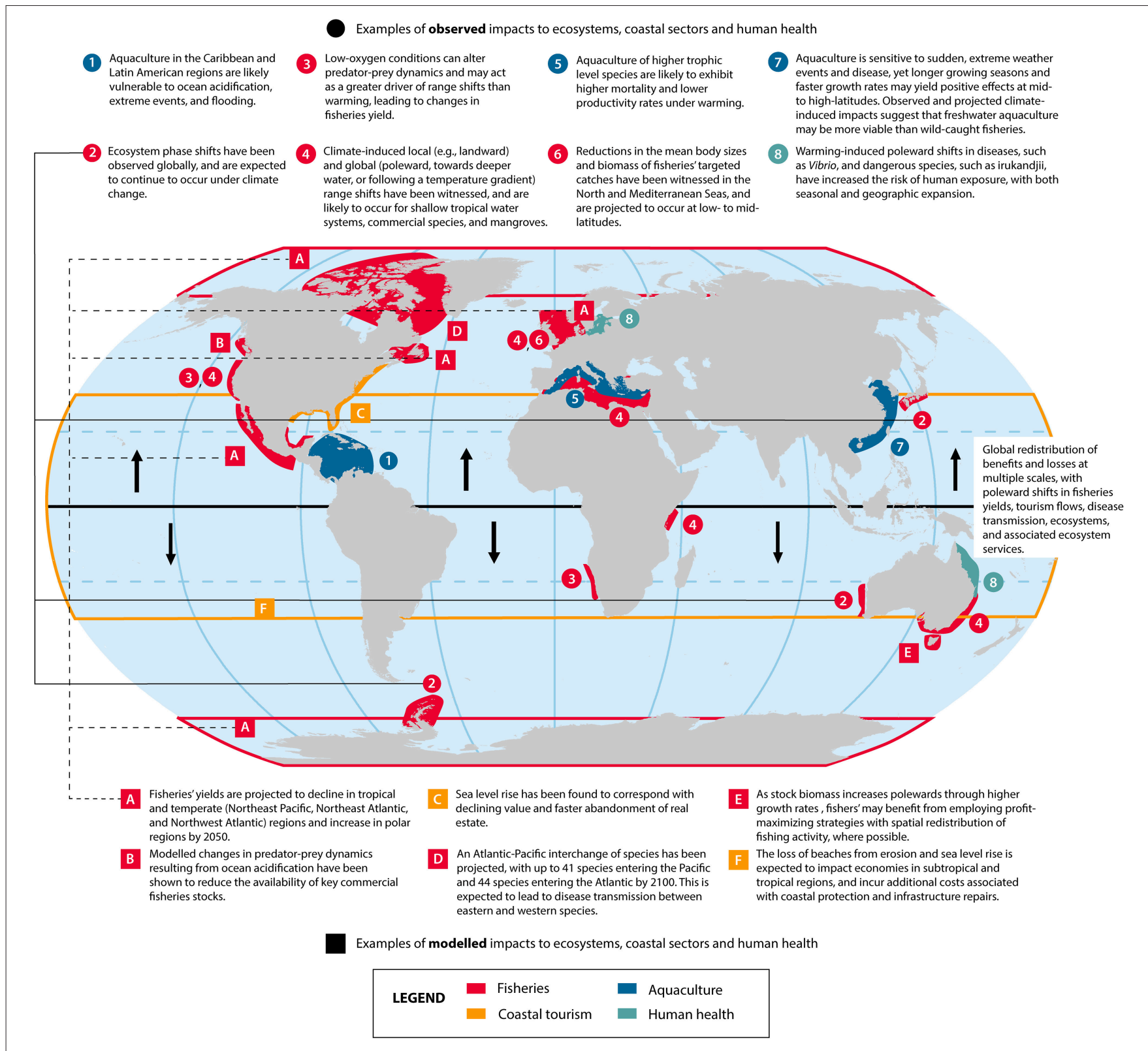

FIGURE 1 | Geography of modeled and observed impacts of climate change on marine and coastal ecosystems, sectors, and human health. This figure, inspired by Figure 3 from Gattuso et al. (2015), shows examples of modeled and observed impacts of climate change, and is not meant to be exhaustive.

be reduced under higher levels of salinity (Mitra, 2013; Di Nitto et al., 2014). Furthermore, the capacity for coastal habitats to shift landwards may be inhibited by the construction of stormresilient infrastructure or coastal development (Lynn et al., 2013). Ecosystem phase shifts and trophic cascades have been observed and projected across multiple ecosystems and latitudes, including tropical coral reefs (Bell J. J. et al., 2013; Inoue et al., 2013; Ainsworth and Mumby, 2014), tidal marshes (Langley et al., 2013), subtropical ecosystems (Milazzo et al., 2012), temperate ecosystems (Wernberg et al., 2012; Thomson et al., 2014; Vergés et al., 2014a), and polar ecosystems (Quartino et al., 2013). These indicate a corresponding poleward shift in the distribution of ecosystem services derived from these species and ecosystems, with diverse outcomes for all coastal sectors and communities.

Noted as an uncertainty in AR5, new research suggests that a species' capacity to track climate velocity may be hindered geographically by "climate sinks," where local climatic conditions differ from the temperature gradients tracked by migrating species (Burrows et al., 2014), and that some species may be unable to keep pace with climate velocity (Hiddink et al., 2014). Other recent issues that have been highlighted include the physiological plasticity to adapt to climate change (Seebacher et al., 2015), potential for genetic bottlenecks to arise in situations where dispersal is constrained (Knutsen et al., 2013), 


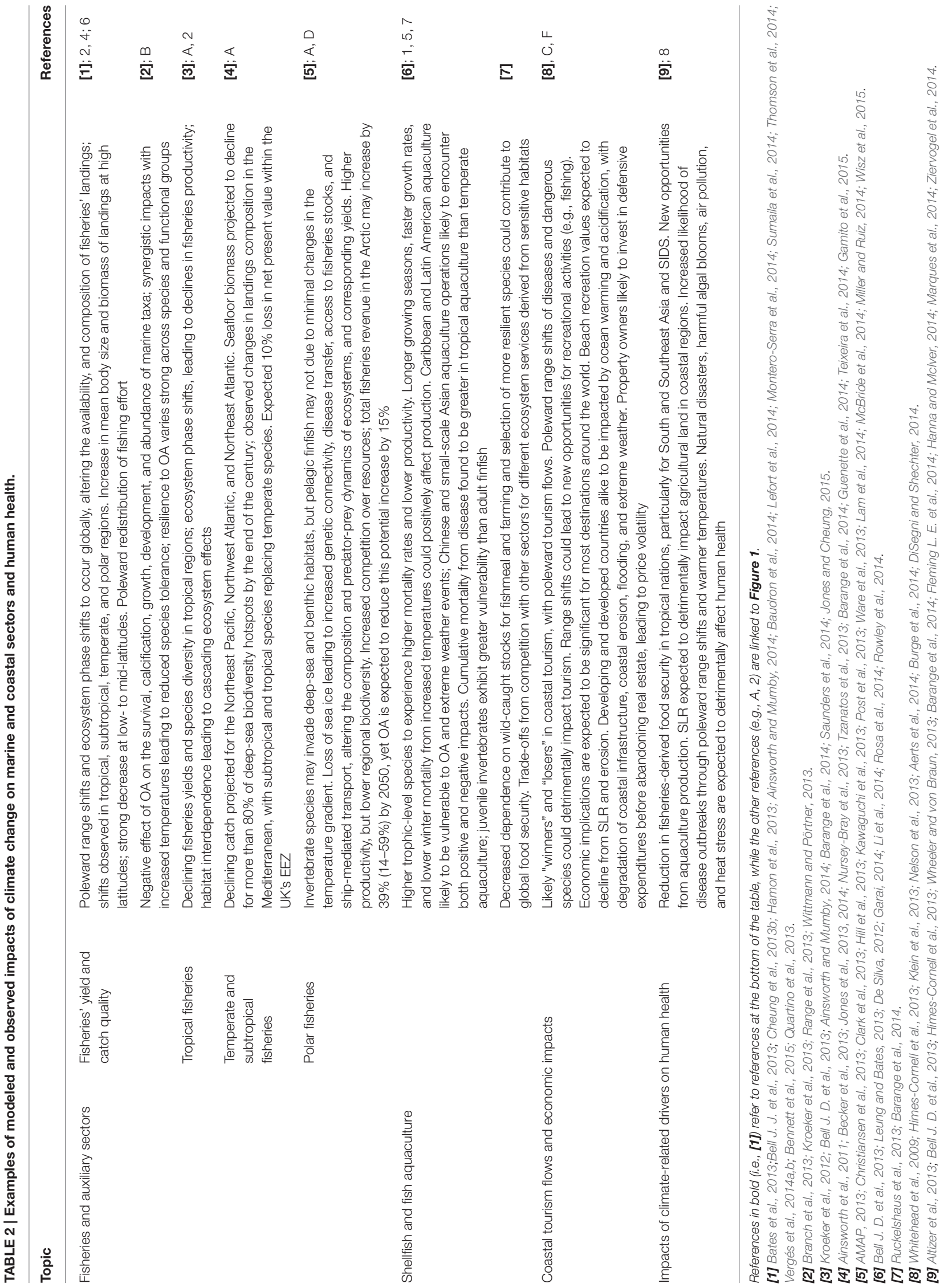


and species' thresholds to hypoxia, temperature and pressure, which may constrain their capacity to migrate in response to climate change (Brown and Thatje, 2014). These findings inform our understanding of how regional compositions of fisheries' landings are likely to change as climate change progresses, and of how these changes are likely to affect local economies and food security.

While recent studies continue to emphasize the vulnerability of tropical communities to climate change, new research suggests the capacity and conditions of the coral reef ecosystems upon which they depend to acquire tolerance to warmer temperatures (Logan et al., 2013; Palumbi et al., 2014) and to recover from bleaching events (Roff et al., 2014). However, this capacity is less certain under cumulative pressures, with taxon-specific responses (Vega Thurber et al., 2013; Palumbi et al., 2014; Silbiger et al., 2014; Whalan and Webster, 2014).

New research on observed and projected climate-induced impacts suggest that sustainable freshwater aquaculture may be more viable than wild-caught fisheries under climate change (Bell J. D. et al., 2013; Rosa et al., 2014; Richards et al., 2015), thereby contributing to global food security (Barange et al., 2014). Increased temperatures are expected to lead to higher growth rates among some cultivated species (e.g., tilapia, carp), while the capacity to control for environmental variables and the likelihood of increased rainfall may yield greater resilience and opportunities for tropical and subtropical aquaculture production (Rosa et al., 2014; Richards et al., 2015). However, changes in the efficiency of aquaculture production associated with an increased prevalence of disease under warmer temperatures are uncertain, and may detrimentally affect human health (Himes-Cornell et al., 2013; Leung and Bates, 2013; Rosa et al., 2014; Rowley et al., 2014). Moreover, new research highlights the potential for trade-offs to occur as coastal sectors compete for different ecosystem services derived from habitats that are sensitive to climate change (Ruckelshaus et al., 2013).

Since AR5, efforts to characterize and value ecosystem services in the context of climate change have been strengthened, with a specific focus on ecosystem-based adaptation (Lavery et al., 2013; Nelson et al., 2013; Roebeling et al., 2013; Fanning, 2014; Spalding et al., 2014). Coastal vegetative habitats have been highlighted as potential and economically efficient means of achieving multiple

\section{REFERENCES}

Aerts, J. C., Botzen, W. J., and Emanuel, K. (2014). Evaluating flood resilience strategies for coastal megacities. Science 344, 473-475. doi: $10.1126 /$ science. 1248222

Ahmed, N., Occhipinti-Ambrogi, A., and Muir, J. F. (2013). The impact of climate change on prawn postlarvae fishing in coastal Bangladesh: socioeconomic and ecological perspectives. Mar. Policy 39, 224-233. doi: 10.1016/j.marpol.2012. 10.008

Ainsworth, C. H., and Mumby, P. J. (2014). Coral-algal phase shifts alter fish communities and reduce fisheries production. Glob. Change Biol. 21, 165-172. doi: $10.1111 /$ gcb.12667

Ainsworth, C. H., Samhouri, J. F., Busch, D. S., Cheung, W. W. L., Dunne, J., and Okey, T. A. (2011). Potential impacts of climate change on Northeast objectives by combining habitat restoration and climate change mitigation strategies (Nelson et al., 2013; Ross and Adam, 2013; Tokoro et al., 2014; Wong et al., 2014). Research continues to focus on the role of coastal habitats in carbon sequestration and storage, supporting the restoration and cultivation of such habitats to aid climate mitigation efforts (Duarte et al., 2013; Spalding et al., 2014).

Lastly, research continues to indicate that climate-induced changes in tourism flows are likely to create "winners" and "losers," with opportunities and losses arising from changes in environmental conditions and destinations' attractiveness. These changes could lead to substantial geospatial shifts in economic costs and benefits associated with tourism revenue and coastal infrastructure protection and repairs (Whitehead et al., 2009; Nelson et al., 2013; DiSegni and Shechter, 2014). Moreover, increased threat from invasive species (e.g., jellyfish), diseases, and extreme weather could reduce the attractiveness of destinations to tourists (Himes-Cornell et al., 2013; Klein et al., 2013; DiSegni and Shechter, 2014).

\section{AUTHOR CONTRIBUTIONS}

LW led the review and the development of the manuscript, and created Figure 1. WC designed and coordinated the review, contributed to the development of the manuscript, and provided feedback on all components of the manuscript. AM, AR, and US contributed to the development of the manuscript and provided feedback at various stages of its development.

\section{ACKNOWLEDGMENTS}

This is a product of "The Oceans 2015 Initiative", an expert group supported by the Prince Albert II of Monaco Foundation, the Ocean Acidification International Coordination Centre of the International Atomic Energy Agency, the BNP Paribas Foundation, and the Monegasque Association for Ocean Acidification. WC also acknowledges funding support from the Nippon Foundation-University of British Columbia Nereus Program, and Natural Sciences and Engineering Council of Canada. URS and WC are grateful for funding supporting for the Social Sciences and Humanities Research Council of Canada through the OceanCanada partnership grant project.

Pacific marine foodwebs and fisheries. ICES J. Mar. Sci. 68, 1217-1229. doi: 10.1093/icesjms/fsr043

Altizer, S., Ostfeld, R. S., Johnson, P. T. J., Kutz, S., and Harvell, C. D. (2013). Climate change and infectious diseases: from evidence to a predictive framework. Science 341, 514-519. doi: 10.1126/science.1239401

AMAP (2013). AMAP Assessment 2013: Arctic Ocean Acidification Monitoring and Assessment Programme (AMAP). Oslo: Arctic Monitoring and Assessment Programme (AMAP), viii + 99 .

Andersson, A. J., Yeakel, K. L., Bates, N. R., and de Putron, S. J. (2013). Partial offsets in ocean acidification from changing coral reef biogeochemistry. Nat. Clim. Change 4, 56-61. doi: 10.1038/nclimate2050

Arent, D. J., Tol, R. S. J., Faust, E., Hella, J. P., Kumar, S., Strzepek, K. M., et al. (2014). "Key economic sectors and services," in Climate Change 2014: Impacts, Adaptation, and Vulnerability. Part A: Global and Sectoral Aspects. Contribution 
of Working Group II to the Fifth Assessment Report of the Intergovernmental Panel of Climate Change, eds C. B. Field, V. R. Barros, D. J. Dokken, K. J. Mach, M. D. Mastrandrea, T. E. Bilir, et al. (Cambridge, UK: New York, NY; Cambridge University Press), 659-708.

Astthorsson, O. S., Valdimarsson, H., Gudmundsdottir, A., and Oskarsson, G. J. (2012). Climate-related variations in the occurrence and distribution of mackerel (Scomber scombrus) in Icelandic waters. ICES J. Mar. Sci. 69, 1289-1297. doi: 10.1093/icesjms/fss084

Ateweberhan, M., Feary, D. A., Keshavmurthy, S., Chen, A., Schleyer, M. H., and Sheppard, C. R. C. (2013). Climate change impacts on coral reefs: synergies with local effects, possibilities for acclimation, and management implications. Mar. Pollut. Bull. 74, 526-539. doi: 10.1016/j.marpolbul.2013.06.011

Ban, S. S., Graham, N. A. J., and Connolly, S. R. (2014). Evidence for multiple stressor interactions and effects on coral reefs. Glob. Change Biol. 20, 681-697. doi: $10.1111 / \mathrm{gcb} .12453$

Barange, M., Merino, G., Blanchard, J. L., Scholtens, J., Harle, J., Allison, E. H., et al. (2014). Impacts of climate change on marine ecosystem production in societies dependent on fisheries. Nat. Clim. Change 4, 211-216. doi: $10.1038 /$ nclimate2119

Barnhart, K. R., Overeem, I., and Anderson, R. S. (2014). The effect of changing sea ice on the physical vulnerability of Arctic coasts. Cryosphere 8, 1777-1799. doi: $10.5194 /$ tc-8-1777-2014

Bates, A. E., Barrett, N. S., Stuart-Smith, R. D., Holbrook, N. J., Thompson, P. A., and Edgar, G. J. (2013). Resilience and signatures of tropicalization in protected reef fish communities. Nat. Clim. Change 4, 62-67. doi: 10.1038/nclimate2062

Bates, A. E., Pecl, G. T., Frusher, S., Hobday, A. J., Wernberg, T., Smale, D. A., et al. (2014). Defining and observing stages of climate-mediated range shifts in marine systems. Glob. Environ. Change 26, 27-38. doi: 10.1016/j.gloenvcha.2014.03.009

Baudron, A. R., Needle, C. L., Rijnsdorp, A. D., and Tara Marshall, C. (2014). Warming temperatures and smaller body sizes: synchronous changes in growth of North Sea fishes. Glob. Change Biol. 20, 1023-1031. doi: 10.1111/gcb.12514

Bauer, J. E., Cai, W.-J., Raymond, P. A., Bianchi, T. S., Hopkinson, C. S., and Regnier, P. A. G. (2013). The changing carbon cycle of the coastal ocean. Nature 504, 61-70. doi: 10.1038/nature12857

Becker, A. H., Acciaro, M., Asariotis, R., Cabrera, E., Cretegny, L., Crist, P., et al. (2013). A note on climate change adaptation for seaports: a challenge for global ports, a challenge for global society. Clim. Change 120, 683-695. doi: 10.1007/s10584-013-0843-z

Bell, J., Ganachaud, A., Gehrke, P., Hobday, A., Hoegh-Guldberg, O., Johnson, J., et al. (2013). "Vulnerability of fisheries and aquaculture to climate change in Pacific island countries and territories," in Priority Adaptations to Climate Change for Pacific Fisheries and Aquaculture: Reducing Risks and Capitalizing on Opportunities, eds P. Gehrke, A. Hobday, O. Hoegh-Guldberg, J. Johnson, R. Le Borgne, P. Lehodey, et al. (Rome: FAO), 25-109. Available online at: http://horizon.documentation.ird.fr/exl-doc/pleins_textes/divers1307/010058314.pdf

Bell, J. D., Ganachaud, A., Gehrke, P. C., Griffiths, S. P., Hobday, A. J., HoeghGuldberg, O., et al. (2013). Mixed responses of tropical Pacific fisheries and aquaculture to climate change. Nat. Clim. Change 3, 591-599. doi: 10.1038/ nclimate 1838

Bell, J. J., Davy, S. K., Jones, T., Taylor, M. W., and Webster, N. S. (2013). Could some coral reefs become sponge reefs as our climate changes? Glob. Change Biol. 19, 2613-2624. doi: 10.1111/gcb.12212

Bennett, S., Wernberg, T., Harvey, E. S., Santana-Garcon, J., and Saunders, B. J. (2015). Tropical herbivores provide resilience to a climate-mediated phase shift on temperate reefs. Ecol. Lett. 18, 714-723. doi: 10.1111/ele.12450

Bopp, L., Resplandy, L., Orr, J. C., Doney, S. C., Dunne, J. P., Gehlen, M., et al. (2013). Multiple stressors of ocean ecosystems in the 21st century: projections with CMIP5 models. Biogeosciences 10, 6225-6245. doi: 10.5194/bg-10-62 25-2013

Boyd, P. W., Sundby, S., and Pörtner, H. O. (2014). "Cross-chapter box on net primary production in the ocean," in Climate Change 2014: Impacts, Adaptation, and Vulnerability. Part A: Global and Sectoral Aspects. Contribution of Working Group II to the Fifth Assessment Report of the Intergovernmental Panel of Climate Change, eds C. B. Field, V. R. Barros, D. J. Dokken, K. J. Mach, M. D. Mastrandrea, T. E. Bilir, et al. (Cambridge, UK: New York, NY; Cambridge University Press), 133-136.
Bramanti, L., Movilla, J., Guron, M., Calvo, E., Gori, A., Dominguez-Carrió, C., et al. (2013). Detrimental effects of ocean acidification on the economically important Mediterranean red coral (Corallium rubrum). Glob. Change Biol. 19, 1897-1908. doi: 10.1111/gcb.12171

Branch, T. A., DeJoseph, B. M., Ray, L. J., and Wagner, C. A. (2013). Impacts of ocean acidification on marine seafood. Trends Ecol. Evol. 28, 178-186. doi: $10.1016 /$ j.tree.2012.10.001

Brisson, C. P., Coverdale, T. C., and Bertness, M. D. (2014). Salt marsh die-off and recovery reveal disparity between the recovery of ecosystem structure and service provision. Biol. Conserv. 179, 1-5. doi: 10.1016/j.biocon.2014.08.013

Brown, A., and Thatje, S. (2014). The effects of changing climate on faunal depth distributions determine winners and losers. Glob. Change Biol. 21, 173-180. doi: $10.1111 / \mathrm{gcb} .12680$

Burge, C. A., Mark Eakin, C., Friedman, C. S., Froelich, B., Hershberger, P. K., Hofmann, E. E., et al. (2014). Climate change influences on marine infectious diseases: implications for management and society. Annu. Rev. Mar. Sci. 6, 249-277. doi: 10.1146/annurev-marine-010213-135029

Burrows, M. T., Schoeman, D. S., Richardson, A. J., Molinos, J. G., Hoffmann, A., Buckley, L. B., et al. (2014). Geographical limits to species-range shifts are suggested by climate velocity. Nature 507, 492-495. doi: 10.1038/nature12976

Busch, D. S., Harvey, C. J., and McElhany, P. (2013). Potential impacts of ocean acidification on the Puget Sound food web. ICES J. Mar. Sci. 70, 823-833. doi: 10.1093/icesjms/fst061

Calbet, A., Sazhin, A. F., Nejstgaard, J. C., Berger, S. A., Tait, Z. S., Olmos, L., et al. (2014). Future climate scenarios for a coastal productive planktonic food web resulting in microplankton phenology changes and decreased trophic transfer efficiency. PLoS ONE 9:e94388. doi: 10.1371/journal.pone.0094388

Chan, N. C. S., and Connolly, S. R. (2012). Sensitivity of coral calcification to ocean acidification: a meta-analysis. Glob. Change Biol. 19, 282-290. doi: $10.1111 / \mathrm{gcb} .12011$

Chavez, F. P., Messié, M., and Pennington, J. T. (2011). Marine primary production in relation to climate variability and change. Annu. Rev. Mar. Sci. 3, 227-260. doi: 10.1146/annurev.marine.010908.163917

Cheung, W. W. L., Pauly, D., and Sarmiento, J. L. (2013c). How to make progress in projecting climate change impacts. ICES J. Mar. Sci. 70, 1069-1074. doi: 10.1093/icesims/fst133

Cheung, W. W. L., Lam, V. W. Y., Sarmiento, J. L., Kearney, K., Watson, R., and Pauly, D. (2009). Projecting global marine biodiversity impacts under climate change scenarios. Fish Fish. 10, 235-251. doi: 10.1111/j.1467-2979.2008.00315.x

Cheung, W. W. L., Sarmiento, J. L., Dunne, J. P., Frölicher, T. L., Lam, V. W., Palomares, M. D., et al. (2013b). Shrinking of fishes exacerbates impacts of global ocean changes on marine ecosystems. Nat. Clim. Change 3, 254-258. doi: 10.1038/nclimate1691

Cheung, W. W. L., Watson, R., and Pauly, D. (2013a). Signature of ocean warming in global fisheries catch. Nature 497, 365-368. doi: 10.1038/nature12156

Christiansen, J. S., Mecklenburg, C. W., and Karamushko, O. V. (2013). Arctic marine fishes and their fisheries in light of global change. Glob. Change Biol. 20, 352-359. doi: 10.1111/gcb.12395

Church, J. A., Clark, P. U., Cazenave, A., Gregory, J. M., Jevrejeva, S., Levermann, A., et al. (2013). "Sea level change," in Climate Change 2013: The Physical Science Basis. Contribution of Working Group I to the Fifth Assessment Report of the Intergovernmental Panel on Climate Change, ed T. F. Stocker (Cambridge: Cambridge University Press), 1137-1216.

Ciscar, J.-C., Iglesias, A., Feyen, L., Szabó, L., Van Regemorter, D., Amelung, B., et al. (2011). Physical and economic consequences of climate change in Europe. Proc. Natl. Acad. Sci. U.S.A. 108, 2678-2683. doi: 10.1073/pnas.1011 612108

Clark, G. F., Stark, J. S., Johnston, E. L., Runcie, J. W., Goldsworthy, P. M., Raymond, B., et al. (2013). Light-driven tipping points in polar ecosystems. Glob. Change Biol. 19, 3749-3761. doi: 10.1111/gcb.12337

Constable, A. J., Melbourne-Thomas, J., Corney, S. P., Arrigo, K. R., Barbraud, C. Barnes, D. K. A., et al. (2014). Climate change and Southern Ocean ecosystems I: how changes in physical habitats directly affect marine biota. Glob. Change Biol. 20, 3004-3025. doi: 10.1111/gcb.12623

de Lavergne, C., Palter, J. B., Galbraith, E. D., Bernardello, R., and Marinov, I. (2014). Cessation of deep convection in the open Southern Ocean under anthropogenic climate change. Nat. Clim. Change 4, 278-282. doi: $10.1038 /$ nclimate2132 
De Silva, S. S. (2012). “Climate change impacts: challenges for aquaculture," in Proceedings on the Global Conference on Aquaculture Farming the Waters for People and Food, eds R. P. Subasinghe, J. R. Arthur, D. M. Bartley, S. S. De Silva, M. Halwart, N. Hishamunda, et al. (Rome: Food and Agricultural Organization of the United Nations), 75-110.

Deutsch, C., Berelson, W., Thunell, R., Weber, T., Tems, C., McManus, J., et al. (2014). Centennial changes in North Pacific anoxia linked to tropical trade winds. Science 345, 665-668. doi: 10.1126/science.1252332

Di Nitto, D., Neukermans, G., Koedam, N., Defever, H., Pattyn, F., Kairo, J. G., et al. (2014). Mangroves facing climate change: landward migration potential in response to projected scenarios of sea level rise. Biogeosciences 11, 857-871. doi: 10.5194/bg-11-857-2014

DiSegni, D. M., and Shechter, M. (2014). "Socioeconomic aspects: human migrations, tourism and fisheries," in The Mediterranean Sea: Its History and Present Challenges, eds S. Goffredo and Z. Dubinsky (Netherlands: Springer), 571-575. doi: 10.1007/978-94-007-6704-1_34

Dixson, D. L., Abrego, D., and Hay, M. E. (2014). Chemically mediated behavior of recruiting corals and fishes: a tipping point that may limit reef recovery. Science 345, 892-897. doi: 10.1126/science. 1255057

Duarte, C. M., Losada, I. J., Hendriks, I. E., Mazarrasa, I., and Marbà, N. (2013). The role of coastal plant communities for climate change mitigation and adaptation. Nat. Clim. Change 3, 961-968. doi: 10.1038/nclimate1970

Eyre, B. D., Andersson, A. J., and Cyronak, T. (2014). Benthic coral reef calcium carbonate dissolution in an acidifying ocean. Nat. Clim. Change 4, 969-976. doi: $10.1038 /$ nclimate2380

Fabbri, E., and Dinelli, E. (2014). "Physiological responses of marine animals towards adaptation to climate changes," in The Mediterranean Sea: Its History and Present Challenges, eds S. Goffredo and Z. Dubinsky (Netherlands: Springer), 401-417. doi: 10.1007/978-94-007-6704-1_23

Fanning, A. L. (2014). "Towards valuing climate change impacts on the ecosystem services of a Uruguayan Coastal Lagoon," in International Perspectives on Climate Change, eds W. Leal Filho, F. Alves, S. Caeiro, and U. M. Azeiteiro (Cham: Springer International Publishing), 61-77.

FAO (2014). The State of World Fisheries and Aquaculture. Rome: Food and Agriculture Organization of the United Nations. Rome: Food and Agriculture Organization of the United Nations, 243. Available online at: http://www.fao.org/3/d1eaa9a1-5a71-4e42-86c0-f2111f07de16/i3720e.pdf

Feary, D. A., Pratchett, M. S. J., Emslie, M., Fowler, A. M., Figueira, W. F., Luiz, O. J., et al. (2013). Latitudinal shifts in coral reef fishes: why some species do and others do not shift. Fish Fish. 15, 593-615. doi: 10.1111/faf.12036

Feehan, C. J., and Scheibling, R. E. (2014). Effects of sea urchin disease on coastal marine ecosystems. Mar. Biol. 161, 1467-1485. doi: 10.1007/s00227-014-2452-4

Fleming, A., Hobday, A. J., Farmery, A., van Putten, E. I., Pecl, G. T., Green, B. S., et al. (2014). Climate change risks and adaptation options across Australian seafood supply chains - A preliminary assessment. Clim. Risk Manag. 1, 39-50. doi: 10.1016/j.crm.2013.12.003

Fleming, L. E., McDonough, N., Austen, M., Mee, L., Moore, M., Hess, P., et al. (2014). Oceans and human health: a rising tide of challenges and opportunities for Europe. Mar. Environ. Res. 99, 16-19. doi: 10.1016/j.marenvres.2014.05.010

Gamito, R., Teixeira, C. M., and Costa, M. J. (2013). Climate-induced changes in fish landings of different fleet components of Portuguese fisheries. Reg. Environ. Change 13, 413-421. doi: 10.1007/s10113-012-0358-6

Gamito, R., Teixeira, C. M., Costa, M. J., and Cabral, H. N. (2015). Are regional fisheries' catches changing with climate? Fish. Res. 161, 207-216. doi: 10.1016/j.fishres.2014.07.014

Ganachaud, A., Gupta, S. A., Brown, J. N., Evans, K., and Maes, C., Muir, L. C., et al. (2012). Projected changes in the tropical Pacific Ocean of importance to tuna fisheries. Clim. Change 119, 163-179. doi: 10.1007/s10584-012-0631-1

Garai, J. (2014). "The impacts of climate change on the livelihoods of coastal people in Bangladesh: a sociological study," in International Perspectives on Climate Change, eds W. Leal Filho, F. Alves, S. Caeiro, and U. M. Azeiteiro (Cham: Springer International Publishing), 151-163.

Gattuso, J.-P., Brewer, P. G., Hoegh-Guldberg, O., Kleypas, J. A., Pörtner, H. O., and Schmidt, D. N. (2014a). "Cross-chapter box on ocean acidification," in Climate Change 2014: Impacts, Adaptation, and Vulnerability. Part A: Global and Sectoral Aspects. Contribution of Working Group II to the Fifth Assessment Report of the Intergovernmental Panel of Climate Change, eds C. B. Field, V. R. Barros, D. J. Dokken, K. J. Mach, M. D. Mastrandrea, T. E.
Bilir, et al. (Cambridge, UK: New York, NY: Cambridge University Press), $129-131$.

Gattuso, J.-P., Hoegh-Guldberg, O., and Pörtner, H. O. (2014b). "Cross-chapter box on coral reefs," in Climate Change 2014: Impacts, Adaptation, and Vulnerability. Part A: Global and Sectoral Aspects. Contribution of Working Group II to the Fifth Assessment Report of the Intergovernmental Panel of Climate Change, eds C. B. Field, V. R. Barros, D. J. Dokken, K. J. Mach, M. D. Mastrandrea, T. E. Bilir, et al. (Cambridge, UK: New York, NY: Cambridge University Press), 97-100.

Gattuso, J.-P., Magnan, A., Billé, R., Cheung, W. W. L., Howes, E. L., Joos, F., et al. (2015). Contrasting futures for ocean and society from different anthropogenic $\mathrm{CO}_{2}$ emissions scenarios. Science 349:aac4722. doi: 10.1126/science.aac4722

Gilly, W. F., Beman, J. M., Litvin, S. Y., and Robison, B. H. (2013). Oceanographic and biological effects of shoaling of the oxygen minimum zone. Annu. Rev. Mar. Sci. 5, 393-420. doi: 10.1146/annurev-marine-120710-100849

Grottoli, A. G., Warner, M. E., Levas, S. J., Aschaffenburg, M. D., Schoepf, V., McGinley, M., et al. (2014). The cumulative impact of annual coral bleaching can turn some coral species winners into losers. Glob. Change Biol. 20, 3823-3833. doi: $10.1111 /$ gcb. 12658

Guenette, S., Araújo, J. N., and Bundy, A. (2014). Exploring the potential effects of climate change on the Western Scotian Shelf ecosystem, Canada. J. Mar. Syst. 134, 89-100. doi: 10.1016/j.jmarsys.2014.03.001

Gurney, G. G., Melbourne-Thomas, J., Geronimo, R. C., Aliño, P. M., and Johnson, C. R. (2013). Modelling coral reef futures to inform management: can reducing local-scale stressors conserve reefs under climate change? PLOS ONE 8:e80137. doi: 10.1371/journal.pone.0080137

Hamon, K. G., Frusher, S. D., Little, L. R., Thébaud, O., and Punt, A. E. (2013). Adaptive behaviour of fishers to external perturbations: simulation of the Tasmanian rock lobster fishery. Rev. Fish. Biol. Fish. 24, 577-592. doi: 10.1007/s11160-013-9302-1

Hanna, E. G., and McIver, L. (2014). "19 small island states-canaries in the coal mine of climate change and health," in Climate Change and Global Health, (Butler, PA; Wallingford: UK: CABI), 181-192.

Hewson, I., Button, J. B., Gudenkauf, B. M., Miner, B., Newton, A. L., Gaydos, J. K., et al. (2014). Densovirus associated with sea-star wasting disease and mass mortality. Proc. Natl. Acad. Sci. U.S.A. 111, 17278-17283. doi: $10.1073 /$ pnas.1416625111

Hiddink, J. G., Burrows, M. T., and García Molinos, J. (2014). Temperature tracking by North Sea benthic invertebrates in response to climate change. Glob. Change Biol. 21, 117-129. doi: 10.1111/gcb.12726

Hill, S. L., Phillips, T., and Atkinson, A. (2013). Potential climate change effects on the habitat of Antarctic krill in the weddell quadrant of the Southern Ocean. PLoS ONE 8:e72246. doi: 10.1371/journal.pone.0072246

Himes-Cornell, A., Allen, S., Auad, G., Boatman, M., Clay, P. M., Herrick, S., et al. (2013). "Impacts of climate change on human uses of the Ocean and Ocean services," in Oceans and Marine Resources in a Changing Climate Oceans and Marine Resources in a Changing Climate, (Washington, DC: Island Press/Center for Resource Economics), 64-118.

Hollowed, A. B., Barange, M., Beamish, R. J., Brander, K., Cochrane, K., Drinkwater, K., et al. (2013). Projected impacts of climate change on marine fish and fisheries. ICES J. Mar. Sci. 70, 1023-1037. doi: 10.1093/icesjms/fst081

Howes, E. L., Joos, F., Eakin, C. M., and Gattuso, J.-P. (2015). An updated synthesis of the observed and projected impacts of climate change on the chemical, physical and biological processes in the oceans. Front. Mar. Sci. 2:36. doi: 10.3389/fmars.2015.00036

Inoue, S., Kayanne, H., Yamamoto, S., and Kurihara, H. (2013). Spatial community shift from hard to soft corals in acidified water. Nat. Clim. Change 3, 683-687. doi: 10.1038/nclimate1855

Johansen, J. L., Messmer, V., Coker, D. J., Hoey, A. S., and Pratchett, M. S. (2013). Increasing ocean temperatures reduce activity patterns of a large commercially important coral reef fish. Glob. Change Biol. 20, 1067-1074. doi: $10.1111 /$ gcb. 12452

Jones, D. O. B., Yool, A., Wei, C.-L., Henson, S. A., Ruhl, H. A., Watson, R. A., et al. (2013). Global reductions in seafloor biomass in response to climate change. Glob. Change Biol. 20, 1861-1872. doi: 10.1111/gcb.12480

Jones, M. C., and Cheung, W. W. L. (2015). Multi-model ensemble projections of climate change effects on global marine biodiversity. ICES J. Mar. Sci. 72, 741-752. doi: 10.1093/icesjms/fsul72 
Jones, M. C., Dye, S. R., Pinnegar, J. K., Warren, R., and Cheung, W. W. L. (2014). Using scenarios to project the changing profitability of fisheries under climate change. Fish Fish 20, 1861-1872. doi: 10.1111/faf.12081

Kawaguchi, S., Ishida, A., King, R., Raymond, B., Waller, N., Constable, A., et al. (2013). Risk maps for Antarctic krill under projected Southern Ocean acidification. Nat. Clim. Change 3, 843-847. doi: 10.1038/nclimate1937

Keeling, R. F., Körtzinger, A., and Gruber, N. (2010). Ocean Deoxygenation in a Warming World. Annu. Rev. Marine. Sci. 2, 199-229. doi: 10.1146/annurev.marine.010908.163855

Klein, S. G., Pitt, K. A., Rathjen, K. A., and Seymour, J. E. (2013). Irukandji jellyfish polyps exhibit tolerance to interacting climate change stressors. Glob. Change Biol. 20, 28-37. doi: $10.1111 /$ gcb. 12408

Knutsen, H., Jorde, P. E., Gonzalez, E. B., Robalo, J., Albretsen, J., and Almada, V. (2013). Climate change and genetic structure of leading edge and rear end populations in a Northwards shifting marine fish species, the corkwing wrasse (Symphodus melops). PLoS ONE 8:e67492. doi: 10.1371/journal.pone.0067492

Kroeker, K. J., Kordas, R. L., Crim, R., Hendriks, I. E., Ramajo, L., Singh, G. S., et al. (2013). Impacts of ocean acidification on marine organisms: quantifying sensitivities and interaction with warming. Glob. Change Biol. 19, 1884-1896. doi: $10.1111 /$ gcb.12179

Kroeker, K. J., Micheli, F., and Gambi, M. C. (2012). Ocean acidification causes ecosystem shifts via altered competitive interactions. Nat. Clim. Change 3, 156-159. doi: 10.1038/nclimate1680

Lam, V. W. Y., Cheung, W. W. L., and Sumaila, U. R. (2014). Marine capture fisheries in the Arctic: winners or losers under climate change and ocean acidification? Fish Fish. doi: 10.1111/faf.12106. [Epub ahead of print].

Langley, J. A., Mozdzer, T. J., Shepard, K. A., Hagerty, S. B., and Patrick Megonigal, J. (2013). Tidal marsh plant responses to elevated CO 2, nitrogen fertilization, and sea level rise. Glob. Change Biol. 19, 1495-1503. doi: 10.1111/gcb.12147

Larsen, J. N., Anisimov, O. A., Constable, A., Hollowed, A. B., Maynard, N., Prestrud, P., et al. (2014). "Polar regions," in Climate Change 2014: Impacts, Adaptation, and Vulnerability. Part B: Regional Aspects. Contribution of Working Group II to the Fifth Assessment Report of the Intergovernmental Panel of Climate Change, eds V. R. Barros, C. B. Field, D. J. Dokken, M. D. Mastrandrea, K. J. Mach, T. E. Bilir, et al. (Cambridge, UK: New York, NY: Cambridge University Press), 1567-1612.

Lavery, P. S., Mateo, M.-Á., Serrano, O., and Rozaimi, M. (2013). Variability in the carbon storage of seagrass habitats and its implications for global estimates of blue carbon ecosystem service. PLOS ONE 8:e73748. doi: 10.1371/journal.pone.0073748

Lefébure, R., Degerman, R., Andersson, A., Larsson, S., Eriksson, L.-O., Båmstedt, U., et al. (2013). Impacts of elevated terrestrial nutrient loads and temperature on pelagic food-web efficiency and fish production. Glob. Change Biol. 19, 1358-1372. doi: 10.1111 /gcb.12134

Lefort, S., Aumont, O., Bopp, L., Arsouze, T., Gehlen, M., and Maury, O. (2014). Spatial and body-size dependent response of marine pelagic communities to projected global climate change. Glob. Change Biol. 21, 154-164. doi: 10.1111/gcb.12679

Leung, T., and Bates, A. E. (2013). More rapid and severe disease outbreaks for aquaculture at the tropics: implications for food security. J. Appl. Ecol. 50, 215-222. doi: 10.1111/1365-2644.12017

Li, S., Yang, Z., Nadolnyak, D., and Zhang, Y. (2014). Economic impacts of climate change: profitability of freshwater aquaculture in China. Aquaculture 47, 1537-1548. doi: 10.1111/are.12614

Lluch-Cota, S. E., Hoegh-Guldberg, O., Karl, D., Pörtner, H. O., Sundby, S., and Gattuso, J. P. (2014). "Cross-chapter box on uncertain trends in major upwelling ecosystems," in Climate Change 2014: Impacts, Adaptation, and Vulnerability. Part A: Global and Sectoral Aspects. Contribution of Working Group II to the Fifth Assessment Report of the Intergovernmental Panel of Climate Change, eds C. B. Field, V. R. Barros, D. J. Dokken, K. J. Mach, M. D. Mastrandrea, T. E. Bilir, et al. (Cambridge, Uk: New York, NY: Cambridge University Press), 149-151.

Logan, C. A., Dunne, J. P., Eakin, C. M., and Donner, S. D. (2013). Incorporating adaptive responses into future projections of coral bleaching. Glob. Change Biol. 20, 125-139. doi: 10.1111/gcb.12390

Lynn, K., Daigle, J., Hoffman, J., Lake, F., Michelle, N., Ranco, D., et al. (2013). The impacts of climate change on tribal traditional foods. Clim. Change 120, 545-556. doi: 10.1007/s10584-013-0736-1
MacKenzie, B. R., Payne, M. R., Boje, J., Høyer, J. L., and Siegstad, H. (2014). A cascade of warming impacts brings bluefin tuna to Greenland waters. Glob. Change Biol 20, 2484-2491. doi: 10.1111/gcb.12597

Magnan, A., Hamilton, J., Rosselló, J., Billé, R., and Bujosa, A. (2012). "Mediterranean Tourism and climate change: identifying future demand and assessing destinations' Vulnerability," in Regional Assessment of Climate Change in the Mediterranean Advances in Global Change Research, (Dordrecht: Springer Netherlands), 337-365.

March, H., Saurí, D., and Llurdés, J. C. (2013). Perception of the effects of climate change in winter and summer tourist areas: the Pyrenees and the Catalan and Balearic coasts, Spain. Reg. Environ. Change 14, 1189-1201. doi: 10.1007/s10113-013-0561-0

Marques, A., Rosa, R., and Nunes, M. L. (2014). "Seafood safety and human health implications," in The Mediterranean Sea: Its History and Present Challenges, eds S. Goffredo and Z. Dubinsky (Netherlands: Springer)589-603. doi: 10.1007/978-94-007-6704-1_36

McBride, M. M., Dalpadado, P., Drinkwater, K. F., Godo, O. R., Hobday, A. J., Hollowed, A. B., et al. (2014). Krill, climate, and contrasting future scenarios for Arctic and Antarctic fisheries. ICES J. Mar. Sci. 71, 1934-1955. doi: 10.1093/icesjms/fsu002

McClanahan, T. R., Graham, N. A., and Darling, E. S. (2014). Coral reefs in a crystal ball: predicting the future from the vulnerability of corals and reef fishes to multiple stressors. Curr. Opin. Environ. Sustainability 7, 59-64. doi: 10.1016/j.cosust.2013.11.028

Merilä, J., and Hendry, A. P. (2014). Climate change, adaptation, and phenotypic plasticity: the problem and the evidence. Evol. Appl. 7, 1-14. doi: 10.1111/eva.12137

Milazzo, M., Mirto, S., Domenici, P., and Gristina, M. (2012). Climate change exacerbates interspecific interactions in sympatric coastal fishes. J. Anim. Ecol. 82, 468-477. doi: 10.1111/j.1365-2656.2012.02034.x

Miller, A. W., and Ruiz, G. M. (2014). Arctic shipping and marine invaders. Nat. Clim. Change 4, 413-416. doi: 10.1038/nclimate2244

Miller, K. A., Munro, G. R., Sumaila, U. R., and Cheung, W. W. L. (2013). Governing marine fisheries in a changing climate: a game-theoretic perspective. Can. J. Agric. Econ. Rev. Can. Agroecon. 61, 309-334. doi: 10.1111/cjag.12011

Mitra, A. (2013). "Impact of climate change on mangroves," in Sensitivity of Mangrove Ecosystem to Changing Climate (New Delhi: Springer), 131-159. doi: 10.1007/978-81-322-1509-7_4

Montero-Serra, I., Edwards, M., and Genner, M. J. (2014). Warming shelf seas drive the subtropicalization of European pelagic fish communities. Glob. Change Biol. 21, 144-153. doi: $10.1111 /$ gcb. 12747

Muhlfeld, C. C., Kovach, R. P., Jones, L. A., Al-Chokhachy, R., Boyer, M. C., Leary, R. F., et al. (2014). Invasive hybridization in a threatened species is accelerated by climate change. Nat. Clim. Change 4, 620-624. doi: 10.1038/ nclimate 2252

Mumby, P. J., Wolff, N. H., Bozec, Y.-M., Chollett, I., and Halloran, P. (2013). Operationalizing the resilience of coral reefs in an era of climate change. Conserv. Lett. 7, 176-187. doi: 10.1111/conl.12047

Munday, P. L., Warner, R. R., Monro, K., Pandolfi, J. M., and Marshall, D. J. (2013). Predicting evolutionary responses to climate change in the sea. Ecol. Lett. 16, 1488-1500. doi: 10.1111/ele.12185

Nelson, E. J., Kareiva, P., Ruckelshaus, M., Arkema, K., Geller, G., Girvetz, E., et al. (2013). Climate change's impact on key ecosystem services and the human well-being they support in the US. Front. Ecol. Environ. 11, 483-893. doi: $10.1890 / 120312$

Noble, I. R., Huq, S., Anokhin, Y. A., Carmin, J., Goudou, D., Lansigan, F. P., et al. (2014). "Adaptation needs and options," in Climate Change 2014: Impacts, Adaptation, and Vulnerability. Part A: Global and Sectoral Aspects. Contribution of Working Group II to the Fifth Assessment Report of the Intergovernmental Panel on Climate Change Climate Change 2014: Impacts, Adaptation, and Vulnerability. Part A: Global and Sectoral Aspects. Contribution of Working Group II to the Fifth Assessment Report of the Intergovernmental Panel on Climate Change, eds C. B. Field, V. R. Barros, D. J. Dokken, K. J. Mach, M. D. Mastrandrea, T. E. Bilir, et al. (Cambridge, UK: New York, NY: Cambridge University Press), 1-36.

Noone, K. J., Sumaila, U. R., and Diaz, R. J. (eds.). (2013). Managing Ocean Environments in a Changing Climate: Sustainability and Economic Perspectives. London: Elsevier. 
Nurse, L. A., McLean, R. F., Agard, J., Briguglio, L. P., Duvat-Magnan, V., Pelesikoti, N., et al. (2014). "Small islands," in Climate Change 2014: Impacts, Adaptation, and Vulnerability. Part B: Regional Aspects. Contribution of Working Group II to the Fifth Assessment Report of the Intergovernmental Panel of Climate Change, eds V. R. Barros, C. B. Field, D. J. Dokken, M. D. Mastrandrea, K. J. Mach, T. E. Bilir, et al. (Cambridge, UK: New York, NY: Cambridge University Press), 1613-1654.

Nursey-Bray, M., Blackwell, B., Brooks, B., Campbell, M. L., Goldsworthy, L., Pateman, H., et al. (2013). Vulnerabilities and adaptation of ports to climate change. J. Environ. Plan. Manag. 56, 1021-1045. doi: 10.1080/09640568.2012.716363

Okey, T. A., Alidina, H. M., Lo, V., and Jessen, S. (2014). Effects of climate change on Canada's Pacific marine ecosystems: a summary of scientific knowledge. Rev. Fish Biol. Fish. 24, 519-559. doi: 10.1007/s11160-014-9342-1

Palumbi, S. R., Barshis, D. J., Traylor-Knowles, N., and Bay, R. A. (2014). Mechanisms of reef coral resistance to future climate change. Science 344, 895-898. doi: 10.1126/science. 1251336

Pauly, D., and Zeller, D. (2016). Catch reconstructions reveal that global marine fisheries catches are higher than reported and declining. Nat. Commun. 7:10244. doi: 10.1038/ncomms10244

Pérez, T., and Vacelet, J. (2014). "Effect of climatic and anthropogenic disturbances on sponge fisheries," in The Mediterranean Sea: Its History and Present Challenges, eds S. Goffredo and Z. Dubinsky (Netherlands: Springer), 577-588. doi: 10.1007/978-94-007-6704-1_35

Pinsky, M. L., and Fogarty, M. J. (2012). Lagged socio-ecological responses to climate and range shifts in fisheries. Clim. Change Lett. 115, 883-891. doi: 10.1007/s10584-012-0599-x

Pinsky, M. L., Worm, B., Fogarty, M. J., Sarmiento, J. L., and Levin, S. A. (2013). Marine taxa track local climate velocities. Science 341, 1239-1242. doi: $10.1126 /$ science. 1239352

Poloczanska, E. S., Brown, C. J., Sydeman, W. J., Kiessling, W., Schoeman, D. S., Moore, P. J., et al. (2013). Global imprint of climate change on marine life. Nat. Clim. Change 3, 919-925. doi: 10.1038/nclimate1958

Poloczanska, E. S., Hoegh-Guldberg, O., Cheung, W., Pörtner, H. O., and Burrows, M. (2014). "Cross-chapter box on observed global responses of marine biogeography, abundance, and phenology to climate change," in Climate Change 2014: Impacts, Adaptation, and Vulnerability. Part A: Global and Sectoral Aspects. Contribution of Working Group II to the Fifth Assessment Report of the Intergovernmental Panel of Climate Change, eds C. B. Field, V. R. Barros, D. J. Dokken, K. J. Mach, M. D. Mastrandrea, T. E. Bilir, et al. (Cambridge,UK: New York, NY: Cambridge University Press), $123-127$.

Portner, J. R., Xie, L., Challinot, A. J., Cochrane, K., Howden, S. M., Iqbal, M. M., et al. (2014). "Food security and food production systems," in Climate Change 2014: Impacts, Adaptation, and Vulnerability. Part A: Global and Sectoral Aspects. Contribution of Working Group II to the Fifth Assessment Report of the Intergovernmental Panel on Climate Change Climate Change 2014: Impacts, Adaptation, and Vulnerability. Part A: Global and Sectoral Aspects. Contribution of Working Group II to the Fifth Assessment Report of the Intergovernmental Panel on Climate Change, eds C. B. Field, V. R. Barros, D. J. Dokken, K. J. Mach, M. D. Mastrandrea, T. E. Bilir, et al. (Cambridge, UK: New York, NY: Cambridge University Press), 485-533.

Pörtner, H. O., Karl, D. M., Cheung, W. W., Lluch-Cota, S. E., Nojiri, Y., Schmit, D. N., et al. (2014). "Ocean systems," in Climate Change 2014: Impacts, Adaptation, and Vulnerability. Part A: Global and Sectoral Aspects. Contribution of Working Group II to the Fifth Assessment Report of the Intergovernmental Panel on Climate Change Climate Change 2014: Impacts, Adaptation, and Vulnerability. Part A: Global and Sectoral Aspects. Contribution of Working Group II to the Fifth Assessment Report of the Intergovernmental Panel on Climate Change, eds C. B. Field, V. R. Barros, D. J. Dokken, K. J. Mach, M. D. Mastrandrea, T. E. Bilir, et al. (Cambridge, UK: New York, NY: Cambridge University Press), 411-484.

Post, E., Bhatt, U. S., Bitz, C. M., Brodie, J. F., Fulton, T. L., Hebblewhite, M., et al. (2013). Ecological consequences of Sea-Ice decline. Science 341, 519-524. doi: $10.1126 /$ science. 1235225

Quartino, M. L., Deregibus, D., Campana, G. L., Latorre, G. E. J., and Momo, F. R. (2013). Evidence of macroalgal colonization on newly ice-free areas following glacial retreat in potter cove (South Shetland Islands), Antarctica. PLoS ONE 8:e58223. doi: 10.1371/journal.pone.0058223
Range, P., Chícharo, M. A., Ben-Hamadou, R., Piló, D., Fernandez-Reiriz, M. J., Labarta, U., et al. (2013). Impacts of CO2-induced seawater acidification on coastal Mediterranean bivalves and interactions with other climatic stressors. Reg. Environ. Change 14, 19-30. doi: 10.1007/s10113-013-0478-7

Richards, R. G., Davidson, A. T., Meynecke, J.-O., Beattie, K., Hernaman, V., Lynam, T., et al. (2015). Effects and mitigations of ocean acidification on wild and aquaculture scallop and prawn fisheries in Queensland, Australia. Fish. Res. 161, 42-56. doi: 10.1016/j.fishres.2014.06.013

Rodriguez, A. B., Fodrie, F. J., Ridge, J. T., Lindquist, N. L., Theuerkauf, E. J., Coleman, S. E., et al. (2014). Oyster reefs can outpace sea-level rise. Nat. Clim. Change 4, 493-497. doi: 10.1038/nclimate2216

Roebeling, P. C., Costa, L., Magalhães-Filho, L., and Tekken, V. (2013). Ecosystem service value losses from coastal erosion in Europe: historical trends and future projections. J. Coast. Conserv. 17, 389-395. doi: 10.1007/s11852-013-0235-6

Roff, G., Bejarano, S., Bozec, Y.-M., Nugues, M., Steneck, R. S., and Mumby, P. J. (2014). Porites and the Phoenix effect: unprecedented recovery after a mass coral bleaching event at Rangiroa Atoll, French Polynesia. Mar. Biol. 161, 1385-1393. doi: 10.1007/s00227-014-2426-6

Rogers, A., Harborne, A. R., Brown, C. J., Bozec, Y.-M., Castro, C., Chollett, I., et al. (2014). Anticipative management for coral reef ecosystem services in the 21st century. Glob. Change Biol. 21, 504-514. doi: 10.1111/gcb.12725

Rosa, R., Marques, A., and Nunes, M. L. (2014). "Mediterranean aquaculture in a changing climate," in The Mediterranean Sea: Its History and Present Challenges, eds. S. Goffredo and Z. Dubinsky (Netherlands: Springer), 605-616. doi: 10.1007/978-94-007-6704-1_37

Ross, P. M., and Adam, P. (2013). Climate change and intertidal wetlands. Biology 2, 445-480. doi: 10.3390/biology2010445

Rowley, A. F., Cross, M. E., Culloty, S. C., Lynch, S. A., Mackenzie, C. L., Morgan, E., et al. (2014). The potential impact of climate change on the infectious diseases of commercially important shellfish populations in the Irish Sea-a review. ICES J. Mar. Sci. 71, 741-759. doi: 10.1093/icesjms/fst234

Ruckelshaus, M., Doney, S. C., Galindo, H. M., Barry, J. P., Chan, F., Duffy, J. E., et al. (2013). Securing ocean benefits for society in the face of climate change. Mar. Policy 40, 154-159. doi: 10.1016/j.marpol.2013.01.009

Salvanes, A. G. V., Bartholomae, C., Yemane, D., Gibbons, M. J., Kainge, P., Krakstad, J.-O., et al. (2015). Spatial dynamics of the bearded goby and its key fish predators off Namibia vary with climate and oxygen availability. Fish. Oceanogr. 24, 88-101. doi: 10.1111/fog.12068

Saunders, M. I., Leon, J. X., Callaghan, D. P., Roelfsema, C. M., Hamylton, S., Brown, C. J., et al. (2014). Interdependency of tropical marine ecosystems in response to climate change. Nat. Clim. Change 4, 724-729. doi: 10.1038/nclimate2274

Saurí, D., Olcina, J., Fernando Vera, J., Martín-Vide, J., March, H., Serra-Llobet, A., et al. (2013). Tourism, Climate Change and Water Resources: Coastal Mediterranean Spain as an Example. Chichester, UK: John Wiley \& Sons, Ltd.

Scott, D. (2014). Climate-Change Implications for Tourism. Oxford, UK: John Wiley \& Sons, Ltd.

Seebacher, F., White, C. R., and Franklin, C. E. (2015). Physiological plasticity increases resilience of ectothermic animals to climate change. Nat. Clim. Change 5, 61-66. doi: 10.1038/nclimate2457

Seth, H., Gräns, A., Sandblom, E., Olsson, C., Wiklander, K., Johnsson, J. I., et al. (2013). Metabolic scope and interspecific competition in sculpins of Greenland are influenced by increased temperatures due to climate change. PLoS ONE 8:e62859. doi: 10.1371/journal.pone.0062859

Shaw, M. R., Overpeck, J. T., and Midgley, G. F. (2014). "Cross-chapter box on ecosystem based approaches to adaptation-emerging opportunities," in Climate Change 2014: Impacts, Adaptation, and Vulnerability. Part A: Global and Sectoral Aspects. Contribution of Working Group II to the Fifth Assessment Report of the Intergovernmental Panel of Climate Change, eds C. B. Field, V. R. Barros, D. J. Dokken, K. J. Mach, M. D. Mastrandrea, T. E. Bilir, et al. (Cambridge, UK: New York, NY: Cambridge University Press), 101-103.

Shoo, L. P., O’Mara, J., Perhans, K., and Rhodes, J. R. (2014). Moving beyond the conceptual: specificity in regional climate change adaptation actions for biodiversity in South East Queensland, Australia. Reg. Environ. Change 14, 435-447. doi: 10.1007/s10113-012-0385-3

Silbiger, N. J., Guadayol, Ò., Thomas, F., and Donahue, M. J. (2014). Reefs shift from net accretion to net erosion along a natural environmental gradient. Mar. Ecol. Progress Ser. 515, 33-44. doi: 10.3354/meps10999 
Silverstein, R. N., Cunning, R., and Baker, A. C. (2014). Change in algal symbiont communities after bleaching, not prior heat exposure, increases heat tolerance of reef corals. Glob. Change Biol. 21, 236-249. doi: 10.1111/gcb.12706

Spalding, M. D., Ruffo, S., Lacambra, C., Meliane, I., Hale, L. Z., Shepard, C. C., et al. (2014). The role of ecosystems in coastal protection: adapting to climate change and coastal hazards. Ocean Coast. Manag. 90, 50-57. doi: 10.1016/j.ocecoaman.2013.09.007

Stock, C. A., Dunne, J. P., and John, J. G. (2014). Global-scale carbon and energy flows through the marine planktonic food web: an analysis with a coupled physical-biological model. Progress Oceanogr. 120, 1-28. doi: 10.1016/j.pocean.2013.07.001

Suikkanen, S., Pulina, S., Engström-Öst, J., Lehtiniemi, M., Lehtinen, S., and Brutemark, A. (2013). Climate change and eutrophication induced shifts in Northern summer plankton communities. PLOS ONE 8:e66475. doi: 10.1371/journal.pone.0066475

Sumaila, U. R., Cheung, W. W. L., and Lam, V. W. Y. (2014). "Climate change effects on the economics and management of marine fisheries," in Handbook on the Economics of Ecosystem Services and Biodiversity, eds P. A. L. D. Nunes, P. Kumar, and T. Dedeurwaerdere (Cheltenham: Edward Elgar Publishing Ltd.), 61-77.

Sumaila, U. R., Cheung, W. W. L., Lam, V. W. Y., Pauly, D., and Herrick, S. (2011). Climate change impacts on the biophysics and economics of world fisheries. Nat. Clim. Change 1, 449-456. doi: 10.1038/nclimate1301

Sunday, J. M., Calosi, P., Dupont, S., Munday, P. L., Stillman, J. H., and Reusch, T. B. H. (2014). Evolution in an acidifying ocean. Trends Ecol. Evol. 29, 117-125. doi: 10.1016/j.tree.2013.11.001

Sydeman, W. J., Garcia-Reyes, M., Schoeman, D. S., Rykaczewski, R. R., Thompson, S. A., Black, B. A., et al. (2014). Climate change and wind intensification in coastal upwelling ecosystems. Science 345, 77-80. doi: $10.1126 /$ science. 1251635

Teixeira, C. M., Gamito, R., Leitão, F., and Cabral, H. N. (2014). Trends in landings of fish species potentially affected by climate change in Portuguese fisheries. Reg. Environ. Change 14, 657-669. doi: 10.1007/s10113-013-0524-5

Thomson, J. A., Burkholder, D. A., Heithaus, M. R., Fourqurean, J. W., Fraser, M. W., Statton, J., et al. (2014). Extreme temperatures, foundation species, and abrupt ecosystem change: an example from an iconic seagrass ecosystem. Glob. Change Biol. 21, 1463-1474. doi: 10.1111/gcb.12694

Tokoro, T., Hosokawa, S., Miyoshi, E., Tada, K., Watanabe, K., Montani, S., et al. (2014). Net uptake of atmospheric CO 2by coastal submerged aquatic vegetation. Glob. Change Biol. 20, 1873-1884. doi: 10.1111/gcb.12543

Tsikliras, A. C., Dinouli, A., Tsiros, V.-Z., and Tsalkou, E. (2015). The Mediterranean and Black Sea fisheries at risk from overexploitation. PLoS ONE 10:e0121188. doi: 10.1371/journal.pone.0121188

Tzanatos, E., Raitsos, D. E., Triantafyllou, G., Somarakis, S., and Tsonis, A. A. (2013). Indications of a climate effect on Mediterranean fisheries. Clim. Change 122, 41-54. doi: 10.1007/s10584-013-0972-4

Vasilakopoulos, P., Maravelias, C. D., and Tserpes, G. (2014). The alarming decline of Mediterranean fish stocks. Curr. Biol. 24, 1643-1648. doi: 10.1016/j.cub.2014.05.070

Vega Thurber, R. L., Burkepile, D. E., Fuchs, C., Shantz, A. A., McMinds, R., and Zaneveld, J. R. (2013). Chronic nutrient enrichment increases prevalence and severity of coral disease and bleaching. Glob. Change Biol. 20, 544-554. doi: $10.1111 / \mathrm{gcb} .12450$

Vergés, A., Steinberg, P. D., Hay, M. E., Poore, A. G. B., Campbell, A. H., Ballesteros, E., et al. (2014a). The tropicalization of temperate marine ecosystems: climate-mediated changes in herbivory and community phase shifts. Proc. R. Soc. B Biol. Sci. 281:20140846. doi: 10.1098/rspb.2014.0846

Vergés, A., Tomas, F., Cebrián, E., Ballesteros, E., Kizilkaya, Z., Dendrinos, P., et al. (2014b). Tropical rabbitfish and the deforestation of a warming temperate sea. J. Ecol. 102, 1518-1527. doi: 10.1111/1365-2745.12324

Ware, C., Berge, J., Sundet, J. H., Kirkpatrick, J. B., Coutts, A. D. M., Jelmert, A., et al. (2013). Climate change, non-indigenous species and shipping: assessing the risk of species introduction to a high-Arctic archipelago. Divers. Distrib. 20, 10-19. doi: $10.1111 /$ ddi. 12117
Wassmann, P., Duarte, C. M., and Agusti, S. (2011). Footprints of climate change in the Arctic marine ecosystem. Glob. Change Biol. 17, 1235-1249. doi: $10.1111 / j .1365-2486.2010 .02311 . x$

Weatherdon, L. V., Ota, Y., Jones, M. C., Close, D. A., and Cheung, W. W. L. (2016). Projected scenarios for coastal First Nations' fisheries catch potential under climate change: management challenges and opportunities. PLOS ONE 1:e0145285. doi: 10.1371/journal.pone.0145285

Wenger, S. J., Som, N. A., Dauwalter, D. C., Isaak, D. J., Neville, H. M., Luce, C. H., et al. (2013). Probabilistic accounting of uncertainty in forecasts of species distributions under climate change. Glob. Change Biol. 19, 3343-3354. doi: $10.1111 / \mathrm{gcb} .12294$

Wernberg, T., Smale, D. A., Tuya, F., Thomsen, M. S., Langlois, T. J., de Bettignies, T., et al. (2012). An extreme climatic event alters marine ecosystem structure in a global biodiversity hotspot. Nat. Clim. Change 3, 78-82. doi: 10.1038/nclimate1627

Whalan, S., and Webster, N. S. (2014). Sponge larval settlement cues: the role of microbial biofilms in a warming ocean. Sci. Rep. 4:4072. doi: 10.1038/srep04072

Wheeler, T., and von Braun, J. (2013). Climate change impacts on global food security. Science 341, 508-513. doi: 10.1126/science.1239402

Whitehead, J. C., Ben, P., Dumas, C. F., and Bin, O. (2009). Measuring the economic effects of sea level rise on shore fishing. Mitig. Adapt. Strateg. Glob. Change 14, 777-792. doi: 10.1007/s11027-009-9198-1

Whiteman, G., Hope, C., and Wadhams, P. (2013). Climate science: vast costs of Arctic change. Nature 499, 401-403. doi: 10.1038/499401a

Wisz, M. S., Broennimann, O., Gronkjaer, P., Moller, P. R., Olsen, S. M., Swingedouw, D., et al. (2015). Arctic warming will promote AtlanticPacific fish interchange. Nat. Clim. Change 5, 261-265. doi: 10.1038/ nclimate 2500

Wittmann, A. C., and Pörtner, H.-O. (2013). Sensitivities of extant animal taxa to ocean acidification. Nat. Clim. Change 3, 995-1001. doi: 10.1038/nclimate1982

Wolfe, K., Dworjanyn, S. A., and Byrne, M. (2013). Effects of ocean warming and acidification on survival, growth and skeletal development in the early benthic juvenile sea urchin (Heliocidaris erythrogramma). Glob. Change Biol. 19, 2698-2707. doi: $10.1111 /$ gcb.12249

Wong, P. P., Losada, I. J., Gattuso, J. P., Hinkel, J., Khattabi, A., McInnes, K. L., et al. (2014). "Coastal systems and low-lying areas," in Climate Change 2014: Impacts, Adaptation, and Vulnerability. Part A: Global and Sectoral Aspects. Contribution of Working Group II to the Fifth Assessment Report of the Intergovernmental Panel on Climate Change Climate Change 2014: Impacts, Adaptation, and Vulnerability. Part A: Global and Sectoral Aspects. Contribution of Working Group II to the Fifth Assessment Report of the Intergovernmental Panel on Climate Change, eds C. B. Field, V. R. Barros, D. J. Dokken, K. J. Mach, M. D. Mastrandrea, T. E. Bilir, et al. (Cambridge, UK: New York, NY: Cambridge University Press), 361-409.

Woodworth-Jefcoats, P. A., Polovina, J. J., Dunne, J. P., and Blanchard, J. L. (2013). Ecosystem size structure response to 21st century climate projection: large fish abundance decreases in the central North Pacific and increases in the California Current. Glob. Change Biol. 19, 724-733. doi: 10.1111/gcb. 12076

Ziervogel, G., New, M., Archer van Garderen, E., Midgley, G., Taylor, A., Hamann, R., et al. (2014). Climate change impacts and adaptation in South Africa. WIREs Clim. Change 5, 605-620. doi: 10.1111/gcb.12597

Conflict of Interest Statement: The authors declare that the research was conducted in the absence of any commercial or financial relationships that could be construed as a potential conflict of interest.

Copyright (๑) 2016 Weatherdon, Magnan, Rogers, Sumaila and Cheung. This is an open-access article distributed under the terms of the Creative Commons Attribution License (CC BY). The use, distribution or reproduction in other forums is permitted, provided the original author(s) or licensor are credited and that the original publication in this journal is cited, in accordance with accepted academic practice. No use, distribution or reproduction is permitted which does not comply with these terms. 